UDK: 336.74::28-74

Stručni rad

Primljeno: 11. 10. 2021.

Prihvaćeno za štampu: 14. 11. 2021.

\author{
Dr. sc. Hakija Kanurić, docent \\ Univerzitet u Bihaću \\ Islamski pedagoški fakultet \\ E-mail: bakijak@hotmail.com
}

\title{
KRIPTOVALUTE U PRIZMI ISLAMSKOG PRAVA
}

\section{Sažetak}

Kroz dugu historiju ljudske zajednice novac je poprimio različite forme, a kriptovalute su njegovo najnovije izdanje. Ovaj rad ima za cilj predstaviti kriptovalute, kako one funkcioniraju, koje su njihove prednosti i nedostaci i kako ib islamsko pravo tretira.

Za razumijevanje sustine kriptovaluta neophodno je shvatiti nekoliko kljucnih termina, kao što su blockechain, privatni ključevi, elektronski novčanici, rudarenje i sl..

Jedan dio islamskih učenjaka, stanovista je da je novac ekskluzivan naziv za zlato $i$ srebro. Kovanice od drugih metala mimo zlata $i$ srebra, rija je nominalna vrijednost veća od stvarne, ova skupina ne smatra novcem i tretira ib robom. Drugi dio učenjaka novcem naziva sve sto se koristi kao platno sredstvo pri razmjeni dobara, radilo se o zlatu, srebru, bakeru, papiru ili bilo čemu drugom ukoliko bude opíe pribvaćeno kao platno sredstvo.

Islamski ǚenjaci jednoglasni su u stavu da je kovanje novca mimo legitimne državne kovaonice zabranjeno ukoliko predstavlja stvarnu i realnu stetu po zajednicu, a kada je šteta moguća, ali nije stvarna, islamski učenjaci po pitanju izdavanja i stampanja novca od strane drugih, mimo vlasti imaju dva oprečna mišljenja.

Većina savremenih učenjaka stanovišta je da su kriptovalute, poput Bitcoina, zabranjene, znatan dio njï ostao je suzdř̃an, a manji dio ǔ́enjaka smatra kriptovalute dozvoljenim, uz odredene uvjete.

Osnovni argumenti zabrane su činjenica da kriptovalute ne izdaje i ne regulira država, obavijene su velom nepoznanica, pospješuju nelegalne aktivnosti i crno træ̌̌išste, nestabilne su $i$ ophodenje njima lič hazardu $i$ kocki. Dozvola kriptovaluta bazira se na univerzalnom pravilu da je svaka stvar u osnovi dozvoljena sve dok validan argument 
ne potvrdi suprotno te cinjenici da su one postale vrijedna imovina $i$ da obavljaju funkciju novca.

Ključne riječi: kriptovalute, Bitcoin, novac, elektronski novac, islamsko pravo.

\section{Uvod}

Iako već cijelu deceniju slušamo o kriptovalutama taj pojam još uvijek predstavlja novitet i obavijen je velom nepoznanica. Šta su zapravo kriptovalute većini ljudi i nije lako razumjeti jer se vezuju za računarske tehnologije i složene softverske operacije.

Riječ "kripto" dolazi od riječi "kriptiranje" ili šifriranje, a to je matematički pristup zaštite informacija. Kriptografija se koristi da osigura i verificira transakcije i kontrolira stvaranje novih jedinica kriptovalute. S obzirom da proces šifriranja i dešifriranja nije jednostavan, ni kriptovalute nisu jednostavne. Kriptovalute su digitalni zapisi o određenim vrijednostima pohranjenim u digitalnim bazama. Kriptovalute funkcioniraju kao neovisni, decentralizirano kontrolirani i kriptografski šifrirani sistem plaćanja.

Njih kreiraju i koriste pojedinci ili grupe u cijelom svijetu putem posebnih softvera. Kreiraju se na naprednim principima matematike $\mathrm{i}$ računarskog inženjerstva, zbog kojih ih je gotovo nemoguće "probiti" te na taj način duplicirati ili krivotvoriti. Postoje samo na internetu i nije ih izdala središnja banka ili država, niti ih nadzire. Ne postoji nikakva nadređena centralna institucija, vlada, agencija, banka ili korporacija koja izdaje ili vodi računa o tim valutama. Generiraju se isključivo digitalno putem mreže sudionika koji je žele koristiti, a hiljade računara unutar mreže provjeravaju i pohranjuju sve transakcije kriptovaluta. Budući da ih ne reguliraju nacionalne vlade, smatraju se alternativnim valutama - medijima razmjene finansija, koji egzistiraju izvan granica državne monetarne politike. S obzirom na to da ih ne nadzire središnja banka, formalno se ne smatraju novcem.

Vrijednost kriptovaluta utvrđuje se iz sekunde u sekundu na osnovu ponude i potražnje i imaju promjenjivi kurs s glavnim svjetskim valutama, poput eura i dolara, a poznatije kriptovalute mogu se za njih mijenjati na posebnim online tržištima. 
Većina kriptovaluta ima ograničenu ponudu i precizan broj jedinica koje mogu postojati. S vremenom postaje teže proizvesti jedinice kriptovalute, sve dok se gornja granica ne dosegne i kriptovaluta prestane kreirati u potpunosti. Ograničena ponuda štiti kriptovalute od inflacije $\mathrm{i}$ čini ih nalik zlatu i plemenitim metalima jer su ograničene zalihe, za razliku od tradicionalnih valuta koje centralne banke teoretski mogu proizvoditi u neograničenim količinama.

Kriptovalute nazivaju i virtualnim valutama s obzirom na to da postoje samo u elektroničkom obliku i ne vezuju se ni za kakvu fizičku stvar.

Šifrirani kodni sistemi kriptovaluta maskiraju identitet korisnika i čine da se transakcije i tokovi sredstava teško pripisuju određenim pojedincima ili grupama.

Kao što čuvamo novac na računu u banci, isto tako možemo čuvati kriptovalute u "digitalnom novčaniku" na nekoj od internetskih stranica koje pružaju tu uslugu. Svaka transakcija koju vlasnik kriptovalute napravi predstavlja vrlo uređen digitalni zapis, odnosno datoteku koja se sastoji od količine prenesenih jedinica kriptovalute i određenih javnih i tajnih ključeva i adresa "digitalnih novčanika" pošiljatelja i primatelja. Svaku transakciju pošiljalac potpisuje svojim privatnim ključem, a na kraju se transakcija potvrđuje i zapisuje u mreži. Niko u mreži ne može vidjeti privatni ključ, ali može vidjeti da je onaj ko doista posjeduje privatni ključ poslao transakciju. Kriptovalute su potpuno nov koncept plaćanja koji korjenito mijenja način na koji doživljavamo novac. ${ }^{1}$

\footnotetext{
${ }^{1}$ Vidjeti: Urošević Uglješa, Elektronsko poslovanje, str. 1, https://www.ucg.ac.me/skladiste/blog_22181/objava_56875/fajlovi/EP\%20_\%207.p df, pristup: 20. 8. 2021.; Dević Božana, Kriptovalute, Specijalistički diplomski stručni, Ekonomski fakultet, Univerzitet u Splitu, Str. 6, https://urn.nsk.hr/urn:nbn:hr:124:321494, pristup: 20. 8. 2021;

Kriptovalute i blockchain - sve što trebate znati, Službene internetske stranice Evropske unije,

https://ec.europa.eu/croatia/cryptocurrencies_and_blockchain_all_you_need_to_kno w_hr, pristup: 20. 8. 2021.; Šta je bitkoin? Istorija, karakteristike, pred̄nosti $\bar{i}$ mane, Cointelegraf; https://rs.cointelegraph.com/bitcoin-for-beginners/what-iscryptocurrency, pristup: 20. 8. 2021.
} 


\section{Razvoj novca i njegove vrste}

Svevišnji Allah učinio je da ljudi budu u potrebi jedni za drugim, i to od samog početka ljudske egzistencije. Čovjek nije u stanju, ili bi to bilo izuzetno teško, da potpuno sam zadovolji sve svoje životne potrebe bez da se pomogne drugim ljudima. Upravo ta potreba rezultirala je pojavom trampe, razmjene robe za robu. Tako je, naprimjer, lovac kupovao žito od poljoprivrednika dajući mu meso, vunu, kožu i sličnu imovinu koju je posjedovao. Sistem trampe funkcionisao je neko vrijeme, ali je bio sve manje praktičan, jer je teško uskladiti vrijednosti dvije robe koje se mijenjaju s obzirom na to da se neka roba ne može dijeliti na manje dijelove, kao što roba nije praktična za čuvanje kapitala i vrijednosti s kojom bi se vršila kupovina. ${ }^{2}$ Zbog togu su nastajale nove forme i vrste novca, smjenjivale su se i evoluirale srazmjerno potrebama ljudske zajednice, razvoju ekonomije, obima i brzine razmjene dobara i usluga. To nam jasno govori da je monetarni sistem u stalnom razvoju, a u našem vremenu dosegao je nivo kriptovaluta. $\mathrm{S}$ ciljem da dublje razumijemo bit i suštinu novca ukazat ćemo na njegove vrste:

- Robni novac, naziva se još i punovrijedni novac. To je roba koja bude prihvaćena kod ljudi kao sredstvo razmjene, poput svih vrsta stoke, žitarica, soli, datula, a to mogu biti i plemeniti metali poput zlata i srebra. Robni novac ima vlastitu vrijednost.

- Metalni novac, to su kovanice od metala koje se koriste kao sredstvo razmjene, na osnovu mase ili broja. S obzirom na to da se zlato i srebro odlikuje specifičnostima koje drugi metali ne posjeduju kovani su u posebnim oblicima da bi sve kovane jedinice bile jednake mase $\mathrm{i}$ kvalitete te kako bi se olakšala njihova upotreba pri kupoprodaji. Budući da je vrijednost zlata i srebra visoka, upotrijebljene su i kovanice od drugih metala (fulus) kako bi se njima kupovala jeftina i malovrijedna roba, i kako bi se cijena bilo koje robe mogla precizno odrediti. Svijet je prihvatio ove kovanice

\footnotetext{
${ }^{2}$ Vidjeti: Gassan Muhammed eš-Šejh, Et-Te'silul-fikhijju lilu'mlatir-rakmijje - Elbitcoin nemuzedžen, El-Umlatul-iftiradijjetu fil mizan, str. 18-19; Muhamed Osman Šubejr, El-Mu'amelatul-malijjetul-mu'asire fil-fikhil-islami, Darun-nefais, Amman, VI izdanje, 2007., str. 150.
} 
u njihovoj nominalnoj vrijednosti koja je veća od vrijednosti metala od kojeg su sačinjene, sve dok su u opticaju.

- Papirni novac. Kako je razmjena robe poprimala sve veći obim, trgovci su počeli pohranjivati svoju imovinu u trezore kod ljudi koji su se bavili zlatom i razmjenom novca (zlata za srebro i sl.), a zauzvrat su dobivali čekove (potvrde, banknote) na osnovu kojih su mogli podići svoju imovinu. Kako je povjerenje prema izdavačima čekova raslo, trgovci, vlasnici čekova, počeli su ih koristiti kao sredstvo razmjene u trgovini, te bi umjesto zlata u trezoru ponudili ček na osnovu kojeg se to zlato može podići. Primatelji čekova mogli su ih zamijeniti za zlato, ili njima dalje plaćati. Potom su vlade država odlučile da te čekove ozvaniče i izdaju u formi novčanica.

Papirni novac prošao je kroz tri stadija:

a) Zamjenski papirni novac, kojeg vlada izdaje tek nakon što se u cijelosti položi pokriće u zlatu i srebru. Taj novac tretira se čekom koji potvrđuje dug vlade prema posjedniku čeka.

b) Fiducijarni novac s djelimičnim pokrićem. To je papirni novac koji je djelimično pokriven zlatom i srebrom, a preostali dio pokriven je snagom vlade koja ga je izdala. Ova vrsta novca pojavljuje se nakon što je vladama postalo jasno da će vlasnici novca vrlo rijetko tražiti konverziju svih banknota u zlato koje im služi kao pokriće.

c) Fiducijarni novac, a to je novac s pravnim pokrićem, bez stvarnog pokrića u zlatu i srebru, svoju vrijednost i kupovnu moć crpi iz moći i snage države i vlasti koji su ga izdali. To je novac koji je rasprostranjen danas. $\mathrm{Na}$ njegovu upotrebu često se u prošlosti prelazilo u kriznim vremenima, kao što su ratovi, kada bi države stavljale van snage obavezu da zamijeni novac za zlato, nego bi vlade jednostavno štampale količinu novca koja je državi bila potrebna. Pojava fiducijarnog novca vezuje se za Drugi svjetski rat, a potpuni prelazak na fiducijarni novac dogodio se nakon propasti Brettonwoodskoga sistema 1971. ${ }^{3}$ Savremene vlade, emitujući

3 ,Brettonwoodska konferencija je međunarodna konferencija predstavnika 44 države održana 22. VII 1944. u Bretton Woodsu (SAD) radi rješavanja poratnih monetarnih 
novac, oslanjaju se na svoju ekonomsku moć, sposobnost proizvodnje robe i usluga, količinu tvrdih valuta koje izdaju politički i ekonomski stabilne države u njihovom posjedu, polog u zlatu i slične izvore ekonomske moći. Stabilnost novca danas ne ovisi o materijalu od kojega je napravljen, nego o regulatornom djelovanju države.

- Knjižni, depozitni ili žiralni novac. To su vrijednosni papiri koje izdaju banke, kao što su čekovi, mjenice, obveznice i sl. Ovaj novac specifičan je po tome da se plaćanje njime unutar nebankarskoga sektora vrši putem mreže bankarskih računa. Knjižni novac može obavljati funkciju tradicionalnog novca iako se ponekad ne tretira novcem, s obzirom na to da povjerenik nije obavezan prihvatiti takav novac kao sredstvo podmirenja duga. Knjižni novac samo je upis prava koje za banke predstavlja obavezu, a za nefinansijska poduzeća, fizičke osobe i javni sektor, predstavlja potraživanje.

- Digitalni (elektronski) novac. Tehnološkim razvojem i pojavom interneta proširile su se društvene komunikacije kao i poslovne transakcije. Pojavio se novi, do tada nepoznati, trgovački trend gdje kupac ne mora odlaziti u trgovine i tržne centre gdje će pronaći robu i platiti je gotovinskim novcem, nego je u stanju kupiti robu ili uslugu u bilo kojoj zemlji na svijetu putem elektronske trgovine. Budući da se te transakcije odvijaju bez direktnog kontakta pojavila se potreba za novcem koji ne iziskuje fizičko prisustvo kupca i prodavca te se pojavljuje elektronski novac. Prva vrsta elektronskog novca pojavljuje se u formi kreditnih i debitnih kartica koje izdaju lokalne banke u saradnji sa svjetskim korporacijama. Tako su se razvile svjetske korporacije kao što su Visa, Mastercard, American express, nudeći kreditne kartice koje u stvari predstavljaju papirni novac sadržan u elektronskim medijatorima. Potom se pojavljuje novi način digitalnog plaćanja (Pay Pal), a to je jednostavan i

i finansijskih problema, na kojoj je postignut sporazum o kreiranju međunarodnog monetarnog sistema (tzv. Brettonwoodski sistem). Nakon konferencije osnovani su Međunarodni monetarni fond i Međunarodna banka za obnovu i razvoj, a utvrđen je i sistem fiksnih deviznih tečajeva, koji je bio na snazi do 1971.“ Vidjeti: Brettonwoodska konferencija, Hrvatska enciklopedija, mrežno izdanje. Leksikografski zavod Miroslav Krleža, 2021., http://www.enciklopedija.hr/Natuknica.aspx?ID=44191, pristup: 19.11. 2021. 
pouzdan sistem elektronskog plaćanja putem interneta cijene robe $\mathrm{i}$ usluga za osobe i firme. Korisnik ove usluge ne mora otkriti imovinske podatke kao što je broj kartice, datum važenja, vrsta ili bankovni račun, kao što je slučaj s kreditnim karticama. Potrebno je samo da obje strane ugovora imaju otvoren Pay Pal račun, jer taj sistem skida cijenu kupljene robe s računa kupca i prebacuje je na račun prodavca i naplaćuje svoju uslugu.

- Kriptovalute. Nakon elektronskog novca pojavljuju se kriptovalute na čelu s Bitcoinom, o čemu slijedi detaljan tekst. ${ }^{4}$

Evidentno je da je novac prolazio kroz različite stadije i poprimao različite forme, bio je u obliku robe, metala poput bakra, plemenitih metala zlata i srebra, potom se pojavljuje papirnati novac, a potom digitalni novac i kriptovalute. To sve skupa govori da je novac u permanentnom razvoju i da nije sveden na plemenite metale, nego kupovna moć kao što biva putem vlastite, prirodne vrijednosti, biva $\mathrm{i}$ putem pravne vrijednosti $(. . .)^{5}$

\section{Funkcija novca}

Funkcija novca je parametar na osnovu kojeg se određuje da li su kriptovalute novac ili ne, a to igra ključnu ulogu u konačnom statusu kriptovaluta $\mathrm{u}$ islamskom pravu. Isto tako, funkcije novca predstavljale su okosnicu na osnovu koje su mnogi savremeni učenjaci akomodirali novčane valute i ukazali na njihov tretman unutar islamskog prava. U tom smislu Abdullah el-Meni' konstatira: „Ekonomski eksperti stanovišta su da novac ima tri funkcije, kada se implementiraju i ostvare u nekoj konkretnoj materiji ta materija se tretira novcem. Te funkcije su da služe kao univerzalno sredstvo razmjene, univerzalno mjerilo vrijednosti i za pohranjivanje kapitala. “6

\footnotetext{
${ }^{4}$ Vidjeti: Gassan Muhammed eš-Šejh, Et-Te'silul-fikhijju lilu'mlatir-rakmijje - Elbitcoin nemuzedžen, El-Umlatul-iftiradijjetu fil mizan, str. 24-27; Novac, Hrvatska enciklopedija, mrežno izdanje.

${ }^{5}$ Vidjeti: Gassan Muhammed eš-Šejh, Et-Te'silul-fikhijju lilu'mlatir-rakmijje - Elbitcoin nemuzedžen, El-Umlatul-iftiradijjetu fil mizan, str. 20; Novac, Hrvatska enciklopedija, mrežno izdanje.

${ }^{6}$ Abdullah b. Sulejman b. Meni', El-Verekun-nakdij-hakikatuhu, tarihuhu, kimetuhu, hukmuhu, treće izdanje, 1984. KSA, str. 17.
} 
Osnovne funkcije novca su:

- Novac je obračunska jedinica ili mjera vrijednosti. Njime se iskazuje vrijednost nekog ekonomskog dobra ili usluge. Kao što se dužina mjeri u metrima i dužnim jedinicama tako se vrijednost mjeri u novcu i novčanim jedinicama.

- Novac služi kao sredstvo razmjene jer je prihvaćen kao sredstvo plaćanja u razmjeni robe i usluga.

- Novac je sredstvo očuvanja vrijednosti. U novcu se pohranjuje vrijednost na način da vlasnik robe proda robu koja prelazi njegove vlastite potrebe i čuva njenu vrijednost u novcu kako bi u narednom periodu mogao kupiti drugu robu za kojom se pojavi potreba.

- Novac je sredstvo prijenosa vrijednosti na drugoga uz uvjet povrata u nekom budućem vremenu (zajam). Dakle, novac omogućava da se izrazi vrijednost odgođenih plaćanja, odnosno dugova te da se dug podmiri dogovorenim iznosom monetarnih jedinica. Nestabilnost i promjene vrijednosti novca, u porastu ili padu čine novac neprikladnim za računanje vrijednosti odgođenih plaćanja, te neke zemlje i pojedinci odgođena plaćanja računaju u zlatu, srebru i sličnim jedinicama stabilne vrijednosti. ${ }^{7}$

\section{Kriptovalute}

Sud o nekoj stvari ili pojavi rezultat je njene percepcije i predstave o njoj. Da bismo mogli govoriti o statusu kriptovaluta u islamskom pravu, neophodno je imati potpunu predstavu o njima. S ciljem da što potpunije shvatimo bit i suštinu kriptovaluta sumirat ćemo i istaknuti njihova osnovna obilježja i karakteristike:

- Kriptovaluta je kodirana digitalna jedinica. Ne postoji u materijalnom, fizičkom smislu, nije opipljiva poput papirnatog novca. Naprotiv, to je potpuno virtualna valuta, prikazana $\mathrm{u}$ brojkama na posebnim digitalnim bazama.

\footnotetext{
${ }^{7}$ Vidjeti: Gassan Muhammed eš-Šejh, Et-Te'silul-fikhijju lilu'mlatir-rakmijje - Elbitcoin nemuzedžen, El-Umlatul-iftiradijjetu fil mizan, str. 28; Novac, Hrvatska enciklopedija, mrežno izdanje.
} 
- Kodirane su i šifrirane tako da je gotovo nemoguće kopirati ih i falsificirati što ih čini sigurnim.

- Kriptovaluta nije pod nadzorom bilo koje monetarne ili finansijske institucije, ne postoji centralni organ koji je kontrolira i upravlja njenom emisijom, produkcijom i vrijednosti. Ne podržava je i ne stoji iza nje bilo koja zvanična institucija ili svjetska organizacija. S obzirom na to da je potpuno decentralizirana, nadzorni organi nisu u mogućnosti pratiti novčane transakcije koje se odvijaju posredstvom kriptovaluta i tu ne postoje gornje granice, maksimalni iznosi koji se mogu uplatiti i slična ograničenja. S druge strane, kriptovaluti nedostaje zakonska zaštita, kao što joj nedostaje centralno rukovodstvo koje bi moglo blagovremeno reagovati $\mathrm{i}$ izvršiti potrebne korekcije kada to situacija zahtijeva uslijed dinamike tržišta, promjena koje uzrokuje kontinuiran tehnološki napredak i drugih nepredvidivih situacija kao što su sporovi među stranama koje posluju kriptovalutama.

- Kriptovalute imaju stvarnu tržišnu vrijednost i predmet su kupoprodaje u mnogim zemljama svijeta. Neke od njih mogu se zamijeniti za tradicionalne valute putem šifriranih transakcija na posebnim web-portalima posebnih aplikacija ili specijaliziranih bankomata.

- Mogućnost kreiranja i proizvodnje kriptovalute teoretski je data svim ljudima, ali je to složen i zahtjevan softverski proces, kojim se rješavaju složeni matematički zadaci. Tu se i rađaju određene sumnje budući da nije precizno definirano kakvi se konkretno matematički zadaci u tom procesu rješavaju.

- Kupoprodaja putem kriptovaluta odvija se digitalnim putem direktno između dva subjekta bez ikakvih drugih posrednika. Ne postoji medijator koji organizira proces kupoprodaje, naprotiv sve se odvija po sistemu direktnog umrežavanja računara bez autorizacije na nekom centralnom serveru koji bi transakciju prihvatio ili odbio, nudeći korisniku potpunu slobodu da izvrši transakcije prema bilo kojem subjektu na bilo kom mjestu u svijetu bez ikakvih ograničenja.

- Kriptovalute ograničavaju nadzor vlada i banki i njihov utjecaj na valute, s obzirom na to da se može anonimno prenijeti u bilo kom 
vremenu na bilo koje mjesto u svijetu bez da bude podvrgnuto bilo kakvoj kontroli. Također pružaju mogućnost bilo kom čovjeku da otvori više računa i posjeduje više digitalnih novčanika, a da se to ne vezuje za njegovo ime, adresu ili bilo koji drugi lični podatak. Ova posebnost i odsustvo centralne uprave koja bi nadzirala procese kupoprodaje i novčane transakcije može naširoko otvoriti vrata internacionalnoj zabranjenoj trgovini, poput trgovine ljudima, drogom, oružjem, finansiranja terorizma, pranja novca i drugih zabranjenih kriminalnih radnji. ${ }^{8}$

\section{Kako kriptovalute funkcioniraju?}

Već smo vidjeli da su kriptovalute vrlo kompleksan sistem, međutim kada shvatimo nekoliko koncepata koji reguliraju vrijednost, sigurnost $\mathrm{i}$ integritet kriptovaluta, imat ćemo mnogo jasniju predstavu o njima.

\section{Blockchain (blokčein)}

Blockchain predstavlja temeljnu bazu kriptovaluta, njen izum otvorio je vrata brojnim drugim inovacijama od kojih se najveće tek očekuju. Neki stručnjaci izjavili su da je izum blockchaina jednak izumu interneta. ${ }^{9}$

Naziv „blockchain“ ili „lanac blokova“ insinuira postojanje određenih blokova. Blokovi su virtuelni koncepti unutar računara u kojima se čuvaju određeni zapisi, poput informacija o transakciji ili čak cijele aplikacije. Kada se zapis pohrani u blok, on se dodaje u ,glavnu

\footnotetext{
${ }^{8}$ El-Jahja, Bender b. Abdul Aziz, El-Umlatul-iftiradijjetu-hakikatuha ve ahkamuhalfikhijje, El-Umlatul-iftiradijjetu fil mizan, El-Mu'temer ed-devli al-hamis ašere likulijjetiš-šeri'ati ved-dirasatil-islamijjeti bidžami'atiš-Šarika, Kitabu vekai'ilmu'temer, 2019., str.230-232.
}

http://www.sharjah.ac.ae/ar/Media/Conferences/Vce2019/Pages/default.aspx, pristup: 20.08.2021.

9 Jasir b. Abdurrahman Alu Abdusselam, El-Umlatul-iftiradijje, str. 2. https://ia903401.us.archive.org/16/items/fiqh12001/fiqh12023.pdf, pristup: 20. 8. 2021. 
knjigu“، Glavna knjiga se sastoji od niza blokova i sadrži cijelu povijest pojedinog blockchaina. ${ }^{10}$

Dakle, blockchain je glavna ili javna "knjiga" u koju se zapisuju sve transakcije i vrijednosne izmjene jedinica kriptovaluta. Tako se u bilo kom trenutku može dobiti cijela povijest svih transakcija koje su ikada napravljene u bilo kojoj javnoj kriptovaluti, i upravo to je temelj sigurnosti blockchaina. Svaki se zapis temelji na složenoj matematičkoj kriptografiji i zapisuje se u slijedu, jedan blok šifri iza drugoga stvarajući tako lanac blokova. Stoga nije moguće promijeniti podatke $u$ lancu jer se pritom uzurpira stanje blokova podataka koji se na njemu nalaze.

Blockchain se ne nalazi na jednom mjestu. Svako ko posjeduje jedinicu neke kriptovalute ima i svoj primjerak "blockchain knjige" koji se sinhronizira među svim računarima u mreži.

Transakcija kriptovaluta tehnički se ne dovršava sve dok se ne doda u blockchain, što se obično događa u roku od nekoliko minuta. Jednom kada je transakcija finalizirana, obično je nepovratna. Za razliku od tradicionalnih procesa plaćanja, poput Pay Pala i kreditnih kartica, većina kriptovaluta nema ugrađenu funkciju povrata sredstava iako neke novije kriptovalute imaju rudimentarne osobine povrata.

Vrijeme između pokretanja i finaliziranja transakcije jedinice nisu dostupne za upotrebu nijednoj strani. Lanac blokova na taj način sprečava dvostruko trošenje, ili manipulaciju kriptovaluta kodom kako bi se omogućilo dupliciranje i slanje istih jedinica valute višestrukim primaocima. $^{11}$

10 Čulig Tihomir, Utjecaj kriptovaluta na moderni bankarski sustav, str. 11, Specijalistički diplomski stručni, University of Applied Sciences / Veleučilište u Karlovcu, https://urn.nsk.hr/urn:nbn:hr:128:627392, pristup: 20. 8. 2021.

${ }^{11}$ Vidjeti: Urošević Uglješa, Elektronsko poslovanje, str. 2-3;

Kriptovalute i blockchain - sve što trebate znati, Službene internetske stranice Europske unije, https:/ec.europa.eu/croatia/cryptocurrencies_and_blockchain_all_you_need_to_kno w_hr, pristup:

20. 8. 2021. 


\section{Privatni ključevi}

Vlasnik kriptovalute ima privatni ključ koji potvrđuje njegov identitet i omogućava mu njenu upotrebu. "Ključevi“" su šifre koje su složenije od onih koje svakodnevno koristimo za ulazak u online-račune, poput emaila. Korisnici mogu kreirati svoje privatne ključeve, koji su formirani kao cijeli brojevi dužine od 1 do 78 cifara, ili ih dobiti pomoću generatora slučajnih brojeva. Svaku transakciju pošiljatelj potpisuje svojim privatnim ključem, a na kraju se transakcija potvrđuje i zapisuje u mreži. Bez ključa, vlasnik ne može koristiti svoju kriptovalutu. Ova sigurnosna osobina smanjuje krađu i neovlaštenu upotrebu. Međutim, gubitak privatnog ključa znači gubitak novca. Iako se može kreirati još jedan privatni ključ i ponovo početi akumulacija kriptovaluta, ne mogu se povratiti udjeli zaštićeni starim izgubljenim ključem. Korisnici kriptovalute obično čuvaju svoje privatne ključeve na više digitalnih lokacija koje zbog sigurnosnih razloga uglavnom nisu povezane $\mathrm{s}$ internetom. $^{12}$

\section{Peer-to-peer (sistem direktnog umrežavanja računara)}

Peer-to-peer mreža je koncept povezivanja računara bez središnje tačke (centralnog servera) te koncept dijeljenja datoteka među računarima. Svaki računar pronalazi i izravno komunicira s drugim računarima do kojih može doći velikim brojem različitih puteva, koji se eksponencijalno povećava s brojem računara u mreži. ${ }^{13}$

\section{Novčanici}

Korisnici kriptovalute imaju "novčanike" s jedinstvenim informacijama koje ih potvrđuju kao privremene vlasnike svojih jedinica. Dok privatni ključevi potvrđuju autentičnost transakcije kriptovaluta, novčanici smanjuju rizik krađe za jedinice koje se ne koriste. Novčanici su osjetljivi na hakovanje. Novčanici se mogu čuvati na cloud-ima, internim hard-diskovima ili eksternim uređajima za čuvanje. Bez obzira

\footnotetext{
12 Vidjeti: ibid.

13 Vidjeti: Dević Božana, Kriptovalute, str. 31; Čulig Tihomir, Utjecaj kriptovaluta na moderni bankarski sustav, str. 12;
} 
na način čuvanja novčanika, preporučuje se barem jedna sigurnosna kopija. ${ }^{14}$

\section{Rudari}

Rudari služe kao čuvari zapisa u zajednicama kriptovaluta i indirektni su arbitri vrijednosti valuta. Uz ogromne količine računarske moći rudari koriste visokotehničke metode da provjere kompletnost, tačnost i sigurnost blokovskih lanaca valuta.

Cijeli "blockchain" sistem čine računari povezani u mrežu koji verificiraju određene transakcije. "Rudari" su osobe (ponekad i skup ljudi ili poslovni entiteti) koje dobrovoljno ustupaju svoje računare i računarsku obradu podataka kako bi se potvrdio skup transakcija provedenih u knjizi platnog prometa, odnosno "blockchainu". Za nagradu dobivaju određenu količinu jedinica kriptovalute. Bez rudara, "blockchain" sistem ne bi lako funkcionirao. "Rudarenje" je proces potvrđivanja i dodavanja novih transakcija u "blockchain".

Rudarski rad periodično stvara nove kopije blockchaina, dodajući nedavne, prethodno neprovjerene transakcije koje nisu uključene ni $\mathrm{u}$ jednu prethodnu blockchain kopiju i efektivno dovršava te transakcije.

Izraz "rudari" odnosi se na činjenicu da rad rudara bukvalno stvara bogatstvo u obliku potpuno novih kriptovalutnih jedinica, kao što rudari kopaju vrijedne metale iz zemlje.

Kroz upute u izvornim kodovima kriptovalute se automatski prilagođavaju količini rudarske snage koja radi na stvaranju novih blockchain kopija na način da se kopije teže stvaraju s povećanjem snage rudarenja, a padom snage rudarenja lakše ih je stvoriti.

Iako rudarenje periodično proizvodi nove jedinice kriptovalute, većina kriptovaluta dizajnirana je tako da ima ograničenu količinu koja će se proizvesti i to je ključni garant vrijednosti. Generalno, to znači da rudari dobijaju manje novih jedinica po novom blockchainu kako vrijeme prolazi. Na kraju rudari će za svoj rad dobijati samo naknadu za transakcije, iako se to još nije dogodilo u praksi i možda neće još neko vrijeme. Ako se trenutni trendovi nastave, predviđanja su da će

${ }^{14}$ Vidjeti: Urošević Uglješa, Elektronsko poslovanje, str. 3. 
posljednja Bitcoin jedinica biti 'izrudarena' negdje sredinom 22. vijeka. ${ }^{15}$

\section{Bitcoin (Bitkoin)}

Prva i najpoznatija kriptovaluta je Bitcoin (BTC). Kreirana je 2009. godine od strane anonimnog programera ili skupine programera, pod pseudoimenom Satoshi Nakamoto. Objavili su znanstveni rad pod nazivom Bitcoin: A Peer-to-peer Electronic Cash System u kojem su predstavili tehničke detalje platnog sistema koji bi omogućio pojedincima slanje i primanje uplata bez uključivanja bilo kakvih posredničkih finansijskih institucija. ${ }^{16}$

Bitcoin ima programirano ograničenu količinu od 21 miliona Bitcoina. Bitcoin se sve više posmatra kao legitimno sredstvo razmjene. Mnoge poznate kompanije prihvataju Bitcoin plaćanja. ${ }^{17}$

Vrijednost jednog Bitcoina 2010. godine iznosila je 0.003 američkih dolara, a u maju 2018. cijena tog istog jednog Bitcoina iznosila je preko 9.000 dolara, polovinom aprila 2021. godine vrijednost jednog Bitcoina prelazila je 60.000 dolara, a sada u augustu 2021. cijena jednog Bitcoina iznosi 49. 005.19 dolara. ${ }^{18}$

Nakon Bitcoina pojavile su se i druge kriptovalute koje su, u kreiranju i primjeni, preuzele rješenja iz Bitcoina, izuzev u nekim tehničkim

\footnotetext{
${ }^{15}$ Vidjeti: Urošević Uglješa, Elektronsko poslovanje, str. 4;

Kriptovalute i blockchain - sve što trebate znati, Službene internetske stranice Europske unije,

https://ec.europa.eu/croatia/cryptocurrencies_and_blockchain_all_you_need_to_kno w_hr, pristup:

20. 8. 2021.

${ }^{16}$ Dević Božana, Kriptovalute, Str. 6,

17 Vidjeti: Urošević Uglješa, Elektronsko poslovanje, str. 11.

${ }^{18}$ Kriptovalute i blockchain - sve što trebate znati, Službene internetske stranice

Europske unije,

https://ec.europa.eu/croatia/cryptocurrencies_and_blockchain_all_you_need_to_kno w_hr, pristup: 20. 8. 2021.; https://kalkulator.com.hr/bitcoin, pristup: $\overline{22} .8 . \overline{2} 02 \overline{1}$.
} 
detaljima. Od važnijih kriptovaluta uz Bitcoin su: Litecoin, Dogecoin, Ripple i Ethereum. ${ }^{19}$

\section{Karakteristike Bitcoina}

- Decentraliziranost i nezavisnost od bilo kog organa vlasti.

- Anonimnost, s obzirom na to da digitalni novčanik ne mora biti vezan ni za jednu ličnu informaciju.

- Transparentnost, a to znači da se svaka BTC transakcija, koja je ikada obavljena, čuva na blockchainu. Međutim, praćenje određene Bitcoin adrese i otkrivanje osobe je i dalje skoro nemoguće.

- Brzina, budući da Bitcoin mreža obrađuje isplate gotovo trenutno. Potrebno je svega nekoliko minuta da neko na drugoj strani svijeta primi novac.

- Nepovratnost, jer kada se Bitcoin jednom pošalje nema načina da se transakcija poništi. ${ }^{20}$

\section{Prednosti i nedostaci kriptovaluta}

Već smo mogli vidjeti da kriptovalute u odnosu na tradicionalne donose brojne benefite, ali isto tako nisu bez nedostataka i mana.

\section{Prednosti kriptovaluta}

Glavne prednosti kriptovaluta su:

- Limitirane količine idu u prilog očuvanju vrijednosti. Većina kriptovaluta ima ograničenu ukupnu ponudu (npr. Bitcoin ograničen je na 21 milijun) Niko ne može promijeniti količinu kripto-novčića koji se koriste. Na taj način su kriptovalute imune na inflaciju, poput zlata i srebra.

- Slabljenje državnog monopola. Kriptovalute niko ne kontrolira, nego imaju vlastitu mrežu po kojoj rade na principu decentralizacije (Peer to

\footnotetext{
19 Vidjeti: Ibid, str. 12.

20 Cointelegraf; Šta je bitkoin? Istorija, karakteristike, prednosti i mane, https://rs.cointelegraph.com/bitcoin-for-beginners/what-is-cryptocurrency, pristup: 20. 8. 2021.
} 
peer). O izdavanju i emisiji kriptovalute ne odlučuje politička institucija, već algoritam. Time se izbjegavaju diskrecijske odluke koje mogu dovesti do prevelike inflacije i povećava se transparentnost (svakom ko je sposoban pročitati algoritam) i predvidljivost 'monetarne politike' kriptovalute. Trenutno, vlade i banke nisu u mogućnosti da kontroliraju kriptovalute. Međutim, kako one postaju popularnije, vlade će se više truditi da ih stave pod kontrolu. Kontrolirane kriptovalute bile bi sasvim drugačije vrste valute.

- Robustna zaštita privatnosti. Decentralizacija osigurava gotovo potpunu anonimnost transakcija, što je dobro za privatnost. Ipak, sofisticiranim članovima ove zajednice moguće je otkriti identitet korisnika, novije kriptovalute (post-bitcoin) imaju dodatnu zaštitu koja to znatno otežava.

- Institucijama je teže naplatiti finansijsku naknadu. U represivnim državama vlade mogu lako zamrznuti ili iskoristiti domaće bankovne račune ili preokrenuti transakcije u lokalnoj valuti. Za razliku od tradicionalnih valuta koje podržavaju centralne banke, kriptovalute su gotovo imune od autoritarnih vlastodržaca.

- Jeftinije od tradicionalnih elektronskih transakcija. Sigurnosne karakteristike kriptovaluta uklanjaju potrebu za trećim procesorima plaćanja - poput Visa ili Pay Pal - koji treba da potvrde svaku elektronsku finansijsku transakciju. To eliminira potrebu za obveznim naknadama za transakcije. Naknade za transakcije kriptovaluta uglavnom su manje od $1 \%$ vrijednosti transakcije, nasuprot $1,5 \%$ do $3 \%$ za transakcije putem kreditne kartice i Pay Pala.

- Manji broj prepreka i troškova za međunarodne transakcije. Transakcije su besplatne ili dolaze s nominalnom naknadom bez obzira gdje se pošiljalac i primalac nalaze. Slanje kriptovalute nalikuje slanju e-maila, bez dodatnih naknada za međunarodne transfere i bez posebnih ograničenja na minimalni ili maksimalni iznos koji se može poslati. Transakcije su brze, s prosječnim vremenom od oko deset minuta. Nema troškova za održavanje računa.

- Sigurnost i transparentnost. Hakiranje blockchaina težak je posao, jer zahtijeva istovremeno hakiranje nekoliko hiljada računaa, što je gotovo nemoguće. Transakcije se verificiraju i trajno registriraju u javni 
registar (glavnu knjigu) koji je praktično neizmjenjiv. Svako može vidjeti sve transakcije koje su ikada napravljene. ${ }^{21}$

\section{Nedostaci kriptovaluta}

Pored prednosti kriptovalute imaju i nedostatke, a neke od spomenutih prednosti mogu se interpretirati i kao nedostaci. Glavni nedostaci kriptovaluta su:

- Odsustvo nadzora i kontrole kriptovaluta olakšava aktivnosti crnog tržišta. Vjerovatno je najveći nedostatak kriptovaluta njihova sposobnost da olakšaju nelegalne aktivnosti. Decentralizacija gotovo potpuno osigurava anonimnost transakcija, a to olakšava transakcije povezane s ilegalnim aktivnostima. Kriptovalute su u tom smislu 'nagodnije' od gotovine s obzirom na povećanu mogućnost obrade velikih transakcija. Kriptovalute su, također, sve popularnije oruđe za pranje novca.

- Mogućnost utaje poreza u nekim nadležnostima. Budući da kriptovalute ne reguliraju nacionalne vlade i obično postoje izvan njihove direktne kontrole, pogodne su za utaju poreza. Anonimnost kriptovaluta otežava zapažanje poreznih kršenja zakona.

- Mogućnost gubitka imovine zbog gubitka podataka. Ukoliko se ključni podaci izgube vrijednost u kriptovaluti efektivno se gubi jer se bez potrebnih podataka ne može koristiti. Pristupni podaci mogu biti zauvijek izgubljeni zbog nekog štetnog softvera ili gubitka podataka na internetu. Digitalni novčanici, neophodni za transakcije pomoću kriptovaluta, u praksi su se pokazali nesigurnim.

- Mogućnost visoke volatilnosti ${ }^{22}$ i manipulacije cijenama. Mnoge kriptovalute imaju određeni broj jedinica koncentriranih kod individualaca (često kreatori valuta i bliski saradnici). Ovi vlasnici efikasno kontroliraju zalihe tih valuta, čineći ih osjetljivim na divlje promjene vrijednosti i direktnu manipulaciju. Vrijednost kriptovalute,

21 Vidjeti: Urošević Uglješa, Elektronsko poslovanje, str. 8-9; Dević Božana, Kriptovalute, str. 8; Čulig Tihomir, Utjecaj kriptovaluta na moderni bankarski sustav, str. 13-14.

${ }^{22}$ Volatilnost je brzo kretanje cijena u velikom rasponu. Vidjeti:

https:/capital.com/hr/volatilnost-definicija, pristup: 19. 11. 2021. 
drastično i brzo se mijenja, što može uzrokovati značajnu finansijsku štetu.

- Otežana razmjena za tradicionalnu valutu. Samo najpopularnije kriptovalute imaju namjenske online-berze koje dopuštaju direktnu razmjenu za tradicionalne valute. Mnoge banke ne pružaju usluge kriptovalutama i njihovim korisnicima i odbijaju saradnju sa digitalnovalutnim kompanijama.

- Nema mogućnosti da se poništi transakcija. U praksi se dešavaju greške i postoji realna potreba da se neke transakcije storniraju, međutim nakon nekoliko potvrda transakcije kriptovaluta su nepovratne. Ako dođe do prevare u transakciji s kriptovalutama ne postoji neko kome se može žaliti.

- O kreiranju i izdavanju kriptovalute odlučuje algoritam, ${ }^{23}$ a ne politička institucija što onemogućava diskreciono donošenje odluka i fleksibilnost u suočavanju s nepredvidivim situacijama.

- S tehnološkim napredovanjem, za korištenje kriptovaluta, javljaju se potrebe za sve jačim računarima sa specijaliziranim hardverom i softverom.

- Pravni status kriptovaluta varira od zemlje do zemlje. U nekim zemljama podstiče se upotreba kriptovaluta, dok se u drugima to tretira nelegalnim i zabranjenim.

- Visoka potrošnja električne energije i nepovoljan utjecaj na okolinu. Rudarenje kriptovaluta energetski je vrlo intenzivno. Prema nekim procjenama rudarstvo Bitcoina troši više električne energije nego cijela Danska. Rast potrošnje električne energije povećava razinu emisije $\mathrm{CO} 2 .^{24}$

${ }^{23}$ Algoritam je skup jednostavnih operacija putem kojih možemo pronaći rješenje problema. Algoritmi omogućavaju izvršavanje neke radnje ili rješavanje problema pomoću niza definiranih, poredanih i konačnih uputa. Vidjeti: https://hr.encyclopediatitanica.com/algoritmo, pristup: 19. 11. 2021.

${ }^{24}$ Vidjeti: Urošević Uglješa, Elektronsko poslovanje, str. 9-11; Dević Božana, Kriptovalute, str. 9; Čulig Tihomir, Utjecaj kriptovaluta na moderni bankarski sustav, str. 14-16. 


\section{Digitalni novac i kriptovalute}

Digitalne valute u širem smislu čine sva sredstva plaćanja koja postoje isključivo u elektroničkom obliku. Kriptovalute su specifični oblik digitalnog novca.

Digitalna valuta $u$ užem smislu je digitalni ekvivalent određenoj fiducijarnoj (fiat) valuti ${ }^{25}$ i vezana je za njenu vrijednost. Digitalne valute u ovom obliku trenutno postoje tek kao koncept, međutim sve više zemalja ozbiljno uzima u obzir mogućnost njihovog uvođenja. Trenutno najbolji primjer zemlje koja je već u odmakloj fazi razvoja digitalne inačice vlastite valute je Kina. Njen cilj je pokrenuti korištenje digitalnog juana do 2022. godine te u dugoročnoj perspektivi njime $u$ potpunosti zamijeniti fizički novac. Tematikom digitalne valute ozbiljno se bavi Kraljevina Švedska kao i Evropska središnja banka. Digitalne valute koje ove zemlje planiraju pod nadzorom su centralnih banki od samog početka.

Najznačajniju razliku između kriptovaluta i digitalnih valuta čini proces kreiranja i izdavanja koji je u slučaju kriptovaluta uglavnom decentraliziran, odnosno obavljaju ga sami korisnici valuta, dok kontrolu nad digitalnim valutama koje izdaju centralne banke vrše one same. Digitalni novac u tom smislu je komponenta valutnog sistema i koristi poznate jedinice, poput eura i dolara, reguliran je i kontroliran u okviru vladinog središnjeg bankarskog sistema. Korisnici ove valute ne bi bili anonimni. ${ }^{26}$

Postoje i druge vrste digitalnog novca kreirane na potpuno različitom konceptu u odnosu na kriptovalute, neke od njih imaju pokriće u zlatu ili robi, neke su osmišljene za internu upotrebu među određenim

\footnotetext{
${ }^{25}$ Fiducijarni novac je novac čija je nominalna vrijednost daleko veća od tržišne vrijednosti materijala od kojeg je napravljen, a temelj mu je povjerenje ljudi u njegovu opću prihvatljivost. Vidjeti: Novac, Hrvatska enciklopedija, mrežno izdanje, pristup: 3. 9.2021.

${ }^{26}$ Vidjeti: Čulig Tihomir, Utjecaj kriptovaluta na moderni bankarski sustav, str. 9-10; https://lider.media/poslovna-scena/tehnopolis/koje-su-razlike-izmedu-kriptovaluta-idigitalnih-valuta-136483.
} 
bankama ili korporacijama. ${ }^{27} \mathrm{Te}$ vrste digitalnih valuta nisu predmet ove studije, na njih se ne odnose argumenti zabrane kriptovaluta.

\section{Pojam novca $u$ islamskom pravu}

Prije nego što iznesemo argumente o zabrani i dozvoli kriptovaluta potrebno je osvrnuti se na dva bitna pitanja na kojima se gradi propis kriptovaluta, a to su: da li se kriptovalute tretiraju novcem i da li je izdavanje novca ekskluzivno pravo vlasti?

Definirajući novac, islamski pravnici podijelili su se na dva mišljenja:

Prvi stav je da je novac ekskluzivan naziv za zlato i srebro. To je razlog da kod klasičnih islamskih pravnika često nalazimo izraz „nakdan“, dvojina riječi „nakd“ a što doslovno znači „,dva novca“ čime se aludira na zlato i srebro. Prema jednom dijelu učenjaka koji podržavaju ovaj stav zlato i srebro se nazivaju novcem bili kovani u zlatnike $i$ srebrenjake ili ne, dok se prema drugima novcem naziva isključivo kovano zlato i srebro. ${ }^{28}$ Kovanice od drugih metala mimo zlata i srebra tzv. „fulus“ čija je nominalna vrijednost veća od stvarne, ova skupina ne smatra novcem, nego ih tretira robom. Novac je zlato i srebro jer imaju vlastitu, autentičnu vrijednost, a druge vrste novca to nemaju i stoga im se ne daje isti status kao zlatu i srebru. Iz ovog stava proizilazi da fulus nisu zekatska imovina, tj, zekat na njih nije obavezan kao što je obavezan na novac, osim ako su trgovačka roba i za njih ne važe posebni propisi kamatne robe, pa je dozvoljeno prodavati ih na odgodu i mijenjati za istu vrstu uz razliku u količini. ${ }^{29}$

Ovo je načelno stav šafijskog i hanbelijskog mezheba. Hanefijski mezheb u poglavlju zekata tretira fulus koji su u opticaju novcem i zakat na njih je obavezan, ali ih ne tretira novcem u poglavlju o kamati nego

${ }^{27}$ Usame Es'ad Ebu Husejn, El-Hukmuš-šer'iju lit-te'amuli bil'umlatil-iftiradijje, ElUmlatul-iftiradijjetu fil mizan, El-Mu'temer ed-devli al-hamis ašere li-kulijjetiššeri'ati ved-dirasatil-islamijjeti bidžami'atiš-Šarika, Kitabu vekai'il-mu'temer, 2019., str. 124-125.

http://www.sharjah.ac.ae/ar/Media/Conferences/Vce2019/Pages/default.aspx, pristup: 20. 8. 2021.

${ }^{28}$ Vidjeti: El-Mevsuatul-fikhijjetul-kuvejtijje, Vizaretul-evkafi veš-šu'unil-islamijje, Darus-selasil (1427. h. g.) Kuvajt, 41/172-173.

${ }^{29} \mathrm{I}$ bid, 32/204-206. 
ih tretira robom pa je dozvoljeno zamijeniti npr. jedan fils za dva. To je mišljenje imama Ebu Hanife i Ebu Jusufa, nasuprot mišljenju Muhammeda b. Hasana eš-Šejbanija koji ih tretira novcem i u pitanjima kamate. ${ }^{30}$

Drugi stav islamskih pravnika je da se novcem naziva i tretira sve što se koristi kao platno sredstvo pri razmjeni dobara, radilo se o zlatu, srebru, bakru, koži, papiru ili nečem drugom ukoliko bude opće prihvaćeno kao platno sredstvo.

Rekao je imam Malik: „Kada bi ljudi međusobno prihvatili (komade) kože da na sebi nose žig i oznake, prezirao bih da se prodaju za zlato ili srebro na odgodu. "31 Iz ovog govora se razumije da imam Malik tretira novcem sve što se prihvati za platno sredstvo, jer zamjena novca za novac biva trenutna, bez odgode, i zato prezire odgodu ako bi se taj novac mijenjao za zlato ili srebro.

Ovo je stav imama Muhammeda učenika Ebu Hanife, ${ }^{32}$ kao što smo već spomenuli i jedna predaja od imama Ahmeda, ${ }^{33}$ stav šejhul-islama Ibnu Tejmijje, ${ }^{34}$ i stav kojeg su prihvatili savremeni islamski pravnici. ${ }^{35}$

Ovo je odabrano mišljenje, a podupire ga osvrt na nastanak i razvoj novca koji nam govori da je novac sve što svijet prihvati da bude sredstvo plaćanja. Tome se još može pridodati odsustvo bilo kakvog dokaza u vjerskim izvorima koji bi uputili da se ništa drugo mimo zlata i srebra ne tretira novcem. ${ }^{36}$ Sve što bude opće prihvaćeno kao platno sredstvo je poput zlata i srebra u smislu da služi kao mjerilo vrijednosti

\footnotetext{
${ }^{30}$ Vidjeti: Ibnu 'Abidin, Reddul-muhtari ala ed-Duril-muhtar, Darul-fikri, Bejrut, 1992. II izdanje, 5/175; Elmevsu'atul-fikhijjetul-kuvejtijje, 32/204-206.

${ }^{31}$ El-Mudevvene, Darul-kutubil-ilmijje, 1994., 3/5.

${ }^{32}$ Vidjeti: Ibnu 'Abidin, Reddul-muhtari ala ed-Duril-muhtar, 5/175.

${ }^{33}$ Vidjeti: Ibnu Kudame, El-Mugni,El-Mektebetul-Kahire,1968., 4/5; El-Merdavi, Tashihul-Furu', Mussesetur-risale, Rijad, KSA, 2003.,6/295.

${ }^{34}$ Vidjeti: Medžmu'ul-fetava, Medžmeul-meliki Fehd, Medina, KSA, 1995., 19/251.

${ }^{35}$ Vidjeti: Elmevsu'atul-fikhijjetul-kuvejtijje, 32/204-206.

${ }^{36}$ Vidjeti: Gassan Muhammed eš-Šejh, Et-Te'silul-fikhijju lilu'mlatir-rakmijje - Elbitcoin nemuzedžen, El-Umlatul-iftiradijjetu fil mizan, str. 23.
} 
i ne posjeduje se kako bi se izravno njime koristilo, nego služi kao sredstvo za kupovinu druge imovine, a to je bit i suština novca. ${ }^{37}$

Kada ovo razilaženje klasičnih islamskih pravnika primijenimo na kriptovalute zaključujemo da skupina koja u prvi plan stavlja osnovu fulusa da je roba, a novac je postao tek nakon što ga je narod takvim prihvatio, tretira ih robom i pravi razliku između njih i zlata i srebra $u$ propisima kamate, zekata i slično. Moguće je da bi ova skupina tretirala i kriptovalute robom, jer nisu zlato niti srebro, niti iza njih stoji vlast $i$ država. Ipak to ne možemo kategorično tvrditi s obzirom na to da se fulusi razlikuju od kriptovaluta po tome što su u osnovi roba, materijalni su i opipljivi za razliku od kriptovaluta koje nikada nisu bile roba niti su fizički osjetljivi.

Učenjaci koji su u prvi plan stavili stvarnost fulusa nakon što su napustili svoju osnovu i transformirali se u platno sredstvo, tretira ih novcem i na njih primjenjuje propise novca po pitanju kamate, zekata $i$ slično. Moguće je da bi ova skupina tretirala kriptovalute novcem, jer su postali platno sredstvo, ali to ne možemo kategorično tvrditi budući da je iza fulusa stajala vlast i država za razliku od kriptovaluta s kojima to nije slučaj. ${ }^{38}$

\section{Akomodacija kriptovaluta u islamskom pravu}

Pozivajući se na funkcije novca koje smo spomenuli, zaključujemo da je novac mjerilo vrijednosti robe i usluga, sredstvo razmjene $i$ alat za prijenos i očuvanje vrijednosti. Sva ova svojstva prisutna su u Bitcoinu i sličnim kriptovalutama, jer se njime mjeri vrijednost robe i usluga. Putem njih može se iskazati vrijednost različitih stvari. Postale su sredstvo razmjene s obzirom na to da su ih prihvatile brojne kompanije, pojedinci i neke države, kao što se kriptovalute koriste za čuvanje kapitala. ${ }^{39}$

\footnotetext{
${ }^{37}$ Jasir b. Abdurrahman Alu Abdusselam, El-Umlatul-iftiradijje, str. 12.

${ }^{38}$ Jasir b. Abdurrahman Alu Abdusselam, El-Umlatul-iftiradijje, str. 13.

${ }^{39}$ Vidjeti: Dr. Öğr. Üyesi Adnan ALGÜL, Ahmed Sarhil, El-Bitkvin, mahijetuhu tekjifuhl-fikhijju ve hukmut-te'amuli bihi šer'an, Gümüşhane Üniv. İlahiyat Fakültesi Dergisi, 2019., ISSN: 2146-7900, str. 309,

https://dergipark.org.tr/tr/download/article-file/761699, pristup: 13. 9. 2021.
} 
$\mathrm{S}$ druge strane kriptovalute razlikuju se od tradicionalnog novca $\mathrm{u}$ sljedećem:

- Fizičko postojanje - budući da kriptovalute ne postoje u materijalnom svijetu. Radi se samo o brojevima koje pokazuje digitalni novčanik kreiran u tu svrhu dok je tradicionalni novac materijalan i opipljiv. Ova razlika nije suštinska s obzirom na to da novac ne mora imati vlastitu vrijednost, nego je dovoljna pravna kao što je slučaj sa fijudicarnim valutama.

- Kontrola i regulacija - budući da kriptovalute ne nadzire centralni organ i ne regulira njihovo izdavanje, vrijednost i opticaj kao što ne postoji medijator koji regulira kripto transakcije, nego se odvijaju direktno između dviju strana. S druge strane, tradicionalni novac je pod direktnim nadzorom vlasti putem centralne banke u svemu što ima veze s monetarnom politikom. Ova razlika je bitna i ne može se zanemariti $\mathrm{s}$ obzirom na to da odsustvo nadzora i kontrole povećava nestabilnost $\mathrm{i}$ rizik valute i otvara mogućnost nezakonitih aktivnosti, kao što ćemo navesti u dokazima zabrane kriptovaluta.

- Izdavanje i puštanje u opticaj, budući da se kriptovalute izdaju programski, putem tzv. ,rudarenja“ koje može praktikovati bilo ko dok tradicionalni novac izdaje centralna banka nakon precizne analize udjela robe i usluga naspram novca u opticaju. Ova razlika također je bitna kao što ćemo vidjeti kroz stavove učenjaka o izdavanju novca kao ekskluzivnom pravu vlasti. ${ }^{40}$

Sličnost kriptovaluta s robom ogleda se $u$ tome da ih nije izdala vlast $\mathrm{i}$ iza njih ne stoji državni aparat, imaju tržišnu vrijednost, kupuju se i prodaju poput robe. Ipak, kriptovalute se ne mogu smatrati robom iz sljedećih razloga:

- Strana koja je razvila i pustila u opticaj kriptovalute imala je namjeru da budu novac koji će se koristiti kao sredstvo razmjene u kupoprodaji $\mathrm{i}$ drugim ugovorima $\mathrm{i}$ zbog toga ih nije ispravno smatrati robom.

- Nemaju vlastitu vrijednost za razliku od robe.

${ }^{40}$ Vidjeti: Gassan Muhammed eš-Šejh, Et-Te'silul-fikhijju lilu'mlatir-rakmijje - Elbitcoin nemuzedžen, El-Umlatul-iftiradijjetu fil mizan, str. 35. 
- Dio populacije prihvatio je kriptovalute za novac, koriste ih kao sredstvo razmjene robe i usluga.

- Kriptovaluta je dijeljiva na manje dijelove i time prikladna da predstavlja cijenu za najrazličitije vrijednosti za razliku od robe koja nije za to predviđena. ${ }^{41}$

- Roba neposredno zadovoljava neku od ljudskih potreba što nije slučaj s kriptovalutama. ${ }^{42}$

Rezimirajući podudarnosti kriptovaluta $\mathrm{s}$ tradicionalnim novcem $\mathrm{i}$ razlike među njima te sličnost i razlike s robom, možemo zaključiti da su kriptovalute vrsta novca i to sasvim posebna i ne mogu se smatrati robom.

\section{Da li je izdavanje novca ekskluzivno pravo države?}

Kao što smo već vidjeli kriptovalute emituje softverski program, nakon što su ih kreatori učinili dostupnim na internet mreži i nakon što su ih ljudi prihvatili i počeli koristiti. To znači da kriptovalute izdaju sami njihovi korisnici, a sve se to odvija bez uplita vlada, država ili centralnih banaka. Nameće se pitanje da li je u islamskom pravu dozvoljeno emitovanje novca koji se koristi među ljudima bez dozvole predstavnika vlasti i države?

Mnogi klasični islamski pravnici eksplicite su istaknuli da je kovanje i izdavanje novca (zlatnika i srebrnjaka) ekskluzivno pravo države, a kovanje novca mimo legitimne državne kovaonice zabranjeno.

Hanefijski velikan Ebu Jusuf, rahimehullah o kovanju kvalitetnih srebrnjaka tajno van legitimne državne kovaonice je rekao: „Niko to ne treba činiti, jer je kovanje novca svojstveno vladarima." ${ }^{\text {"43 }}$

Imam Ahmed, rahimehullah, ukazujući na dužnosti vladara i njihovih namjesnika po pitanju novca i brige o njemu rekao je: „Nije ispravno da se srebrnjaci kuju negdje drugo mimo legitimne državne kovaonice

\footnotetext{
${ }^{41}$ Usame Es'ad Ebu Husejn, El-Hukmuš-šer'iju lit-te'amuli bil'umlatil-iftiradijje, ElUmlatul-iftiradijjetu fil mizan, str. 119.

42 Vidjeti: Gassan Muhammed eš-Šejh, Et-Te'silul-fikhijju lilu'mlatir-rakmijje - Elbitcoin nemuzedžen, El-Umlatul-iftiradijjetu fil mizan, str. 37.

${ }^{43}$ Es-Senami Omer b. Muhammed, Nisabul-ihtisabi, El-Mektebetuš-šamile, str.231.
} 
pod nadzorom vladara, jer ako bi se to dozvolilo drugima, činili bi velike nevolje.“44

Imam Nevevi prenoseći stav učenjaka šafijskog mezheba kaže: „Naši učenjaci rekli su: 'Pokuđeno je drugima mimo vladara kovanje zlatnika i srebrnjaka ako su čisti i nepomiješani (a miješano s drugim metalima pokuđeno je i samom vladaru) jer to je jedno od pitanja koja se tiču vlasti i nije sigurno da pri tome neće biti varanja i nereda.'“45

Imam Ebu Hanife i Sevri smatrali su dozvoljenim da se kovani zlatnici i srebrenjaci „razbiju“ i podijele na sitnije dijelove ukoliko to ne šteti zajednici muslimana. ${ }^{46} \mathrm{Na}$ osnovu ovog stava imama Ebu Hanife i Sevrija, neki savremeni učenjaci zaključili su da njih dvojica nisu smatrali da je kovanje zlatnika i srebrenjaka ekskluzivno pravo vladara ukoliko se kuju prema specifikacijama i masama kao što ih kuje i država $\mathrm{i}$ ako to ne donosi štetu zajednici muslimana, ${ }^{47} \mathrm{~s}$ obzirom na to da se usitnjeni zlatnici i srebrenjaci mogu tretirati novom vrstom novca.

Iz navedenog možemo zaključiti da su islamski učenjaci jednoglasni u stavu da drugima osim legitimnog vladara nije dozvoljeno štampati i emitirati novac ukoliko to predstavlja stvarnu i realnu štetu po zajednicu, a kada je šteta moguća ali nije stvarna, islamski učenjaci po pitanju izdavanja i štampanja novca od strane drugih mimo vladara imaju dva različita mišljenja.

Stav da je kovanje novca ekskluzivno pravo vlasti argumentiran je sljedećim dokazima:

- Priprema, izdavanje, nadzor i kontrola novca tradicionalno je jedna od najznačajnijih uloga vlasti na polju ekonomije. Tu ulogu preuzeo je vladar islamske države još od vremena pravednih halifa. Prvi počeci kovanja novca u islamskoj zemlji bili su još u vremenu pravednog halife Omera, r.a., a 75. godine po Hidžri pojavljuju se kovani islamski zlatnici i srebrenjaci s islamskim simbolima. Od tog

\footnotetext{
${ }^{44}$ El-Merdavi, Tashihul-Furu', 4/133.

${ }^{45}$ En-Nevevi, Muhjuddin Jahja b.Šeref, El-Medžmu'u - šerhul-Muhezzebi, Darul-fikr, $6 / 11$.

${ }^{46}$ Vidjeti: El-Belaziri Ahmed b. Jahja, Futuhul-buldan, Mektebetul-Hilal, Bejrut, 1988., str. 452.

${ }^{47}$ Vidjeti: Jasir b. Abdurrahman Alu Abdusselam, El-Umlatul-iftiradijje, str. 14.
} 
vremena nadalje izdavanje novca bilo je isključivo pod nadzorom države. Štaviše, to je jedna od njenih najočitijih i najvažnijih obaveza na polju ekonomije i finansijske politike.

- Opći interes društva i zajednice zahtijeva da izdavanje novca bude isključivo pod nadzorom države, jer se tako najefikasnije sprečava falsificiranje novca i prevare u transakcijama.

- Država je u stanju odrediti potrebnu količinu novca, da bi se ekonomske aktivnosti odvijale na prikladan način, i zaštiti javni i privatni interes građana. Naprimjer, u situaciji kada se poremeti ravnoteža između količine novca stavljenog u opticaj i potražnje za njim, bez adekvatne intervencije, nastat će inflacija ili deflacija novca što će štetiti državi i građanima. ${ }^{48}$

Stav da izdavanje novca nije ekskluzivno pravo vlasti, nego je to dozvoljeno i drugima bazira se na pravilu da je u osnovi sve dozvoljeno, a zabranjeno je samo ono što validan argument izvede iz te osnove. S obzirom na to da u vjerskim tekstovima nema jasnog argumenta koji bi zabranio izdavanje novca drugih mimo vladara to ostaje na svojoj osnovi, odnosno dozvoli, izuzev kada se potvrdi da šteti zajednici te zbog toga bude zabranjeno.

S druge strane izdavanje novca drugih mimo vladara može se zabraniti principom pravne prevencije kako bi se spriječilo varanje i poigravanje $\mathrm{s}$ imovinom ljudi. Stabilnost novca je vitalni interes društva i vlast je dužna zaštititi ga i spriječiti nered na tom polju. ${ }^{49}$

Razmatrajući argumente zabrane uočavamo da se baziraju na zaštiti općeg interesa i da je izdavanje novca ograničeno na vlast kako bi se spriječila šteta kojoj bi društvo u suprotnom bilo izloženo. Kriptovalute ne pretendiraju, barem za sada, da potpuno isključe i zamijene tradicionalne valute, nego obogaćuju ponudu na tržištu valuta. Većina islamskih zemalja nije izdala jasnu zakonsku zabranu kriptovaluta, izuzev Alžira, ${ }^{50}$ a odsustvo takve zabrane implicira da ih vlasti odobravaju i djelimično prihvataju. To se može tretirati odricanjem

\footnotetext{
${ }^{48}$ Vidjeti: Jasir b. Abdurrahman Alu Abdusselam, El-Umlatul-iftiradijje, str. 15-16.

${ }^{49}$ Vidjeti: ibid, str. 16.

50 Vidjeti: Usame Es'ad Ebu Husejn, El-Hukmuš-šer'iju lit-te'amuli bil'umlatiliftiradijje, El-Umlatul-iftiradijjetu fil mizan, str. 119.
} 
vlasti od svog prava na izdavanje ove vrste novca, jer ako bi vlast smatrala da se izdavanjem kriptovaluta uzurpira njeno pravo, izdala bi zakonsku regulativu kojim bi ih zabranila i ophođenje njima tretirala krivičnim djelom, kao što vlast intervenira kada se tradicionalna valuta falsificira, jer time se narušava pravo legitimne vlasti koja ih je izdala. ${ }^{51}$

\section{Stavovi islamskih učenjaka o kriptovalutama}

Islamski učenjaci po pitanju kriptovaluta zauzeli su tri različita stava, neki od njih su ih zabranili, drugi su suzdržani, a treći su ih dozvolili. Prije nego što iznesemo njihove stavove vrijedno je napomenuti da su svi oni složni da su neke kriptovalute zabranjene, budući da su osmišljene kako bi se koristile u nečemu što je vjerom zabranjeno, kao što je kriptovaluta sexcoin i titcoin. ${ }^{52}$

Mišljenja učenjaka koja ćemo ovdje navesti odnose se na Bitcoin i slične kriptovalute bazirane na istom konceptu, a kriptovalute koje se značajno razlikuju u odnosu na njih potrebno je posebno analizirati.

Prvo mišljenje: Kriptovalute su zabranjene. To je stav Generalnog vijeća za islamska pitanja Ujedinjenih Arapskih Emirata, ${ }^{53}$ Egipatskog Vijeća za fetve, ${ }^{54}$ Palestinskog Vijeća za fetve, ${ }^{55}$ Uprave za vjerska pitanja Turske, ${ }^{56}$ zatim učenjaka koji su individualno istraživali ovo

\footnotetext{
51 Vidjeti: ibid, str. 120.

52 Ibid, str. 124.

${ }^{53}$ Oficijelna stranica Generalnog vijeća za islamska pitanja Ujedinjenih Arapskih Emirata, fetva br. 89043, pristup: 26. 8. 2021.

https://www.awqaf.gov.ae/ar/Pages/FatwaDetail.aspx?did=89043

${ }^{54}$ Oficijelna stranica Egipatskog vijeća za fetve, https:/www.daralifta.org/ar/Viewstatement.aspx?sec=media\&ID=5617, pristup: 26. 8. 2021.

55 Palestinsko Vijeće za fetve, fetva br. 1/158, 25. 3. 1439 hidžr. god., https://staff.ppu.edu/jawad/files/316, pristup: 26. 8. 2021.

${ }^{56}$ Izjavili su da je upotreba Bitcoina sa vjerskog aspekta neprikladna. Vidjeti: Proglas Islamskog ekonomskog foruma o legalnosti bitcoina, br. 1/2018, 11. 1. 2018., str. 20; https://ar.islamway.net/book/29586/بيان-منتدى-الاقتصاد-الا-سلامي-بشا-ن-مشروعية-البتكوين , pristup: 26.08.2021.
} 
pitanje od kojih su Abdullah el-Meni', ${ }^{57}$ Ali Džumu'a, ${ }^{58}$ Kehlan b. Nebhan el-Harusi, ${ }^{59}$ Abdussadik b. Halkan. ${ }^{60}$

Drugo mišljenje zastupaju učenjaci koji su ostali suzdržani po pitanju kriptovaluta i nisu ih svrstali među zabranjene stvari, niti među dozvoljene, čekajući da se bit i suština kriptovaluta, način ophođenja njima i posljedice koje iz toga proizilaze još više razjasne. Među tim učenjacima su Abdurrahman b. Nasir el-Berrak, ${ }^{61}$ Muhammed b. Salih el-Munedždžid, ${ }^{62}$ Jusuf eš-Šubejli, ${ }^{63}$ Abdullah el-Mutlak, ${ }^{64}$ Abdulaziz el-Fevzan ${ }^{65}$ i drugi, a suzdržan je ostao i Kolegij islamskog prava pri Organizaciji islamske solidarnosti u Džidi ${ }^{66}$.

Treće mišljenje: Kriptovalute u osnovi su dozvoljene. To mišljenje zastupa Abdullah es-Silmi, ${ }^{67}$ Najif el-Adžmi, ${ }^{68}$ Usame Es'ad Ebu

${ }^{57} \mathrm{https}: / /$ www.youtube.com/watch?v=H12kbv6azFs, pristup: 31. 8. 2021.

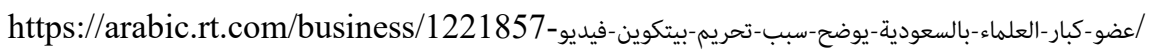

${ }^{58}$ Usame Es'ad Ebu Husejn, El-Hukmuš-šer'iju lit-te'amuli bil'umlatil-iftiradijje, ElUmlatul-iftiradijjetu fil mizan, str. 127.

${ }^{59}$ https://www.youtube.com/watch?v=rjEJQ0dy89I, pristup: 31. 8. 2021.

${ }^{60} \mathrm{https}: / /$ www.youtube.com/watch?v=QBQMKuJjaUg, pristup: 31. 8.2021.

${ }^{61} \mathrm{https}$ ://www.youtube.com/watch?v=0bp-SkfovTc, pristup: 31. 8. 2021.

62 Ibid.

${ }^{63} \mathrm{https}: / /$ www.youtube.com/watch?v=KxikLcHuVt0, pristup: 31. 8. 2021.

${ }^{64} \mathrm{https}$ ://sabq.org/NGZvjV, pristup: 31. 8. 2021.

${ }^{65} \mathrm{https}: / /$ www.youtube.com/watch?v=L4QVRA9U21w, pristup: 31. 8. 2021.

66 https://makkahnewspaper.com/article/1111925/أعمال/مجمع-الفقه-الإسلامي-حكم-التعامل-بالعملات . الرقمية-محل-نظر, pristup: 31. 8. 2021.

${ }^{67}$ Smatra da su kriptovalute poput robe, a ne novca i stoga su u osnovi dozvoljene ukoliko ne postoji poseban razlog zabrane $u$ ophođenju $s$ njima. Vidjeti: https://www.youtube.com/watch?v=MRWq-dVmX9Q, pristup: 31. 8. 2021.

68 Vidjeti: Usame Es'ad Ebu Husejn, El-Hukmuš-šer'iju lit-te'amuli bil'umlatiliftiradijje, El-Umlatul-iftiradijjetu fil mizan, str. 129. 
Husein $^{69}$ kao što se iz Proglasa Islamskog ekonomskog foruma o legalnosti Bitcoina može razumjeti da naginju ovom mišljenju. ${ }^{70}$

\section{Argumenti zabrane kriptovaluta i odgovori na njih}

Prvi dokaz je prethodno pitanje ekskluzivnosti prava na izdavanje novca te da je rezervirano za vlast koja ne stoji iza kriptovaluta. Već smo elaborirali stavove učenjaka o ovom pitanju i iznijeli njihove argumente.

Drugo: Kriptovalute (Bitcoin) obavijenu su velom nepoznanica, od kojih su:

- njihova bit i suština poznati su samo maloj skupini stručnjaka informatičara dok je ostalom svijetu njihova bit nepoznata,

- emituje ih i izdaje nepoznata strana, a osoba ili grupa koja je kreirala mehanizam i sistem kriptovaluta (Bitcoina) anonimna je i nepoznata,

- ne postoji strana koja garantira sigurnost ophođenja kriptovalutama,

- nepoznata je ili ne postoji strana koja ih regulira i njima upravlja,

- nepoznati su ljudi koji ih koriste putem interneta.

To sve skupa rezultira visokim rizikom i velikim nepoznanicama koje šrijat u kupoprodajnim ugovorima ne tolerira. ${ }^{71}$

${ }^{69}$ Kriptovalute smatra dozvoljenim uz dva uvjeta:

- Da se ne koriste za špekulantske poslove, a to je kupnja finansijske imovine s ciljem da se ostvari brz profit njezinom prodajom ubrzo nakon pribavljanja, zbog visokog nivoa rizika i izloženosti imovine gubicima.

- Da ophođenje s kriptovalutama ne bude potpuno anonimno, na način da strana $s$ kojom se posluje kriptovalutama bude transparentna i pouzdana. Vidjeti: Usame Es'ad Ebu Husejn, El-Hukmuš-šer'iju lit-te'amuli bil'umlatil-iftiradijje, El-Umlatuliftiradijjetu fil mizan, str. 130.

70 Proglas Islamskog ekonomskog foruma o legalnosti bitcoina br. 1/2018, 11 . 1.2018., str. 23 i dalje.

71 Vidjeti: Gassan Muhammed eš-Šejh, Et-Te'silul-fikhijju lilu'mlatir-rakmijje - Elbitcoin nemuzedžen, El-Umlatul-iftiradijjetu fil mizan, str. 43; Usame Es'ad Ebu Husejn, El-Hukmuš-šer'iju lit-te'amuli bil'umlatil-iftiradijje, El-Umlatul-iftiradijjetu fil mizan, str. 121. 


\section{Odgovor:}

Nepoznavanje suštine i biti kriptovaluta nije razlog da budu zabranjene jer se može saznati i razumjeti konsultovanjem stručnjaka i brojnih izvora dostupnih na internetu koji su detaljno objasnili princip na kojem funkcioniraju kriptovalute i sve vezano za njih.

Anonimnost osoba ili strana koje koriste kriptovalute nije apsolutna, $\mathrm{s}$ obzirom na to da se kriptovalutama kupuje od poznatih kompanija, marketa, trgovina i slično, naprimjer, samo u Japanu postoji oko deset hiljada firmi koje prihvataju plaćanje kriptovalutama. ${ }^{72}$ Relativna transparentnost $\mathrm{u}$ ophođenju kriptovalutama mogla bi biti uvjet da ophođenje njima bude šerijatom prihvatljivo. ${ }^{73}$

Anonimnost strane koja je izdala kriptovalute i kreirala njihov sistem, strane koja garantira sigurnost i koja ih regulira i kontrolira ne utječe na konačni status kriptovaluta budući da su pravila po kojima se ophodi kriptovalutama javna, transparentna i poznata njihovim konzumentima, a povjerenje koje država pruža tradicionalnim valutama kompenzira blockchain tehnologija koja svojom prirodom i snagom pruža visok nivo sigurnosti. ${ }^{74}$

Ovom odgovoru može se prigovoriti da strana koja je kreirala $\mathrm{i}$ osmislila sistem kriptovaluta i njihov kompleksni mehanizam izdavanja, verifikovanja i procesa razmjene nepoznatog je identiteta, o njoj defakto ne znamo ništa. S obzirom na to da sve do danas nije objavljen naučni stručni rad od strane akreditovane, neutralne internacionalne institucije koji isključuje mogućnost kontrole kriptovaluta i poigravanja s njenim sistemom, ostaje mogućnost da strana koja ih je izdala može kontrolirati kriptovalute pa i ako tvrdi da njen sistem ne dozvoljava nikom da ih regulira ili se s njima poigrava. Tu sumnju jača činjenica da je ostala skrivenog identiteta. Zatim, ako u današnje vrijeme i nije moguće hakirati ili kontrolirati sistem Bitcoina i sličnih kriptovaluta u budućnosti to nije isključeno, jer ono što je danas

\footnotetext{
72 Vidjeti: Usame Es'ad Ebu Husejn, El-Hukmuššser'iju lit-te'amuli bil'umlatiliftiradijje, El-Umlatul-iftiradijjetu fil mizan, str. 122.

${ }^{73}$ Vidjeti: ibid.

${ }^{74}$ Vidjeti: Proglas Islamskog ekonomskog foruma o legalnosti bitcoina. br. 1/2018, 11. 1. 2018., str. 24.
} 
nemoguće, sutra može biti sasvim moguće, naročito kada je u pitanju moderna tehnologija. ${ }^{75}$

Treće: Anonimnost korisnika kriptovaluta pospješuje nezakonite radnje, pranje novca, ucjene, izbjegavanje poreza, crno tržište, trgovinu internacionalno zabranjenom robom, kao što je oružje, droga, ljudski organi i sl.

Većina islamskih pravnika, a naročito hanbelijski i malikijski, primjenjuju načelo pravne prevencije na osnovu kojeg zabranjuju djela koja vode $\mathrm{u}$ haram $\mathrm{i}$ zabranjeno, te su po toj osnovi zabranjene $\mathrm{i}$ kriptovalute. $^{76}$

\section{Odgovor:}

Nezakonita upotreba kriptovaluta je sekundarna, drugorazredna i ne utječe na finalni status kriptovaluta, budući da se nezakonite radnje realizuju i tradicionalnim valutama, koje su preko toga podložne krivotvorenju, a pored toga niko ih nije preventivno zabranio. S druge strane, nezakonita upotreba kriptovaluta može se ograničiti kao što na to ukazuju određene studije. ${ }^{77}$

S obzirom na to da nezakonita upotreba kriptovaluta nije primarna, ne mogu se zabraniti principom pravne prevencije, kao što taj princip uopće nije prihvaćen kod učenjaka hanefijskog i šafijskog mezheba na osnovu argumenata koji se ne mogu zanemariti. ${ }^{78}$

Replicirajući ovom odgovoru može se konstatovati da su nezakonite aktivnosti putem tradicionalnih valuta rijetke i neznatne, lakše se sprečavaju, a počinitelji se mogu identifikovati i krivično goniti, za razliku od kriptovaluta gdje se transakcije odvijaju potpuno bez nadzora

\footnotetext{
75 Vidjeti: Gassan Muhammed eš-Šejh, Et-Te'silul-fikhijju lilu'mlatir-rakmijje - Elbitcoin nemuzedžen, El-Umlatul-iftiradijjetu fil mizan, str. 43-44.

${ }^{76}$ Vidjeti: ibid, str. 39.

77 Vidjeti: Proglas Islamskog ekonomskog foruma o legalnosti bitcoina, br. 1/2018, 11. 1. 2018., str. 24.

78 Vidjeti: Gassan Muhammed eš-Šejh, Et-Te'silul-fikhijju lilu'mlatir-rakmijje - Elbitcoin nemuzedžen, El-Umlatul-iftiradijjetu fil mizan, str. 39.
} 
i kontrole, bez ikakvih ograničenja, a identitet korisnika ostaje skriven što čini praćenje kriminalnih radnji teškim ili nemogućim. ${ }^{79}$

Četvrto: Visoka volatilnost, nagle $\mathrm{i}$ velike promjene vrijednosti kriptovaluta čine ih nestabilnim i nepouzdanim, a ophođenje njima liči kocki i hazardu, s obzirom na to da se desi da u jednom danu izgube više od polovine tržišne vrijednosti ili pak stopostotno uvećaju vrijednost. $^{80}$

Odgovor: Visoka volatilnost i promjene vrijednosti kriptovaluta utječu na njihovu kompetentnost, ali ne utječe na suštinu funkcije novca koju obavljaju, kao i kada se radi o tradicionalnim valutama čija vrijednost, također, može imati visoke oscilacije, ali i pored toga ophođenje njima ne tretira se kockom i hazardom. ${ }^{81}$

\section{Argumenti dozvole i odgovori na njih}

Prvi dokaz ovog mišljenja je univerzalno pravilo u islamskom pravu da je svaka stvar u svojoj osnovi dozvoljena i ostaje na toj dozvoli sve dok validan argument ne potvrdi suprotno. Prema tome, kriptovalute su dozvoljene s obzirom na to da ne postoji jasan argument koji bi ih izveo iz te osnove. ${ }^{82}$

Ovom argumentu replicirano je dokazima prvog mišljenja, tj. da su kriptovalute zabranjene zbog brojnih nepoznanica kojima su obavijene, anonimnosti, tajnosti i visokog rizika kakav islamsko pravo ne tolerira. $^{83}$

\footnotetext{
${ }^{79}$ Vidjeti: Gassan Muhammed eš-Šejh, Et-Te'silul-fikhijju lilu'mlatir-rakmijje - Elbitcoin nemuzedžen, El-Umlatul-iftiradijjetu fil mizan, str. 39-40.

${ }^{80}$ Vidjeti: ibid, str. 39.

${ }^{81}$ Vidjeti: Proglas Islamskog ekonomskog foruma o legalnosti bitcoina, br. 1/2018, 11. 1. 2018., str. 24.

${ }^{82}$ Vidjeti: Gassan Muhammed eš-Šejh, Et-Te'silul-fikhijju lilu'mlatir-rakmijje - Elbitcoin nemuzedžen, El-Umlatul-iftiradijjetu fil mizan, str. 37; Proglas Islamskog ekonomskog foruma o legalnosti bitcoina, br. 1/2018, 11. 1. 2018., str. 23.

${ }^{83}$ Vidjeti: Gassan Muhammed eš-Šejh, Et-Te'silul-fikhijju lilu'mlatir-rakmijje - Elbitcoin nemuzedžen, El-Umlatul-iftiradijjetu fil mizan, str. 37.
} 
Drugi dokaz: Kriptovalute su imovina koja u islamskom pravu ima vrijednost uzimajući $u$ obzir njihovo stvarno stanje te da se kriptovalutama kupuju druge valute, roba i usluge.

Odgovor: Ako prihvatimo da su kriptovalute imovina i da imaju vrijednost, anonimnost izdavača i mnoštvo nepoznanica koje ih obavijaju čine ih zabranjenim zbog visokog rizika i hazarda koji iz toga proizilaze. $^{84}$

Treći dokaz: Kriptovalute načelno obavljaju funkcije novca i tradicionalnih valuta iako ih nisu izdale države i vlade, a ne postoji $\mathrm{u}$ ekonomiji niti u šerijatu ograničenje koje bi ih zabranilo. ${ }^{85}$

U odgovoru na ovaj dokaz navodi se da kriptovalute, iako obavljaju funkcije novca, anonimnost izdavača i preuzimanje uloge centralne banke čini njihovu upotrebu zabranjenom. ${ }^{86}$

\section{Zaključna razmatranja}

S obzirom na to da ne postoji eksplicitan tekstualni dokaz koji izdavanje novca ograničava na državu, nego se izdavanje novca vezuje za vlast s ciljem zaštite općeg interesa, zabrana kriptovaluta samo zbog toga što ih ne izdaju i ne reguliraju vlade i države diskutabilna je. Pravo i obaveza vlasti i države je da štiti opći interes društva i spriječi sve što ga narušava. Ukoliko kriptovalute predstavljaju opasnost po ekonomiju zemlje i njen monetarni sistem, pospješuju nezakonite aktivnosti i slično, vlast ih je dužna zabraniti. Prema tome, legalnost kriptovaluta i odsustvo zakonske zabrane može poslužiti kao indikator da ne ugrožavaju opći interes i da preventivna zabrana nije nužna. Sve dok se na potvrdi da kriptovalute ugrožavaju opći interes ili predstavljaju prijetnju po njega ostaju na izvornoj dozvoli i ne možemo tvrditi da ih islamsko pravo, štiteći opći interes, zabranjuje.

Brojne nepoznanice kojima su kriptovalute ovijene i visok rizik u ophođenju s njima jesu uzroci na osnovu kojih islamsko pravo

\footnotetext{
84 Vidjeti: ibid.

${ }^{85}$ Vidjeti: Proglas Islamskog ekonomskog foruma o legalnosti bitcoina, br. 1/2018, 11. 1. 2018., str. 23.

${ }^{86}$ Vidjeti: Gassan Muhammed eš-Šejh, Et-Te'silul-fikhijju lilu'mlatir-rakmijje - Elbitcoin nemuzedžen, El-Umlatul-iftiradijjetu fil mizan, str. 37.
} 
zabranjuje kupoprodajne ugovore. Međutim, visok rizik i nepoznanice toleriraju se u nekim, iznimnim situacijama, kao što je stanje potrebe. U tom smislu islamsko pravo dozvoljava tzv. „selem“ kupoprodaju, a to je avansni ugovor pri kojoj se prodaje nepostojeća roba, što je vid rizika i neizvjesnosti, ali se tolerira zbog potrebe za takvim ugovorom. Hanefijski učenjak Kemal b. Humam kaže: „Nije tajna da je legalnost selema suprotna analogiji, s obzirom na to da se prodaje nepostojeća roba, ali je taj ugovor nužno prihvaćen na osnovu (hadiskog) teksta i konsenzusa, i to zbog potrebe obje ugovorne strane, prodavca i kupca $(\ldots)^{6687}$ Spomenuta selem prodaja dozvoljena je uz posebne uvjete koji neizvjesnost pri tom ugovoru minimiziraju.

Analogno tome možemo kazati da se kriptovalute dozvoljavaju uz uvjete koji će ih ograničiti na stanje potrebe i minimizirati nepoznanice i rizik, a to su dva uvjeta:

1. Da se ne koriste za špekulacije ${ }^{88}$, nego samo u situaciji kada za njima postoji potreba, kao što je kupovina robe i usluga, transfer novca i sl..

2. Da ophođenje s kriptovalutama ne bude potpuno anonimno, na način da strana s kojom se posluje bude transparentna i pouzdana. ${ }^{89}$

Ovaj propis odnosi se na kriptovalute kakve smo u radu opisali, poput Bitcoina, a kriptovalute koncipirane na drugi način mogu imati različit status, naročito ukoliko se minimiziraju nepoznanice i rizik u ophođenju s njima. Svevišnji Allah najbolje zna.

\section{LITERATURA I IZVORI}

Abdullah b. Sulejman b. Meni', El-Verekun-nakdij - hakikatuhu, tarihuhu, kimetuhu, hukmuhu, treće izdanje, 1984. KSA.

\footnotetext{
${ }^{87}$ Kemal b. Humam, Fethul-Kadir, Darul-fikr, 7/71.

88 Špekulacija je kupovina finansijske imovine s ciljem da se ostvari brz profit njezinom prodajom ubrzo nakon pribavljanja. Vidjeti: https:/www.mojbankar.hr/Kazalo/ŠS/Spekulacija, pristup: 21. 9. 2021.

${ }^{89}$ Slična dva uvjeta da bi kriptovalute bile dozvoljene naveo je Usama Es'ad Ebu Husejn u studiji o kriptovalutama pod naslovom: El-Hukmuš-šer'iju lit-te'amuli bil'umlatil-iftiradijje. Vidjeti: El-Umlatul-iftiradijjetu fil mizan, str. 130.
} 
Čulig Tihomir, Utjecaj kriptovaluta na moderni bankarski sustav, Specijalistički diplomski stručni, University of Applied Sciences / Veleučilište u Karlovcu, https://urn.nsk.hr/urn:nbn:hr:128:627392, pristup: 20. 8. 2021.

Dević Božana, Kriptovalute, Specijalistički diplomski stručni, Ekonomski fakultet, Univerzitet u Splitu, https:/urn.nsk.hr/urn:nbn:hr:124:321494, pristup: 20. 8. 2021;

El-Belaziri Ahmed b. Jahja, Futuhul-buldan, Mektebetul-Hilal, Bejrut, 1988.

El-Jahja, Bender b. Abdul Aziz, El-Umlatul-iftiradijjetu - hakikatuha ve ahkamuhal-fikhijje, El-Umlatul-iftiradijjetu fil mizan, El-Mu'temer eddevli al-hamis ašere li-kulijjetiš-šeri'ati ved-dirasatil-islamijjeti bidžami'atiš-Šarika, Kitabu vekai'il-mu'temer, 2019. http://www.sharjah.ac.ae/ar/Media/Conferences/Vce2019/Pages/default.a spx, pristup: 20. 8. 2021.

El-Merdavi, Tashihul-Furu', Mussesetur-risale, Rijad, KSA, 2003.

El-Mevsuatul-fikhijjetul-kuvejtijje, Vizaretul-evkafi veš-šu'unil-islamijje, Darus-selasil (1427. h. g.) Kuvajt.

En-Nevevi, Muhjuddin Jahja b.Šeref, El-Medžmu'u - šerhul-Muhezzebi, Darul-fikr.

Es-Senami Omer b. Muhammed, Nisabul-ihtisabi, El-Mektebetuš-šamile.

Gassan Muhammed eš-Šejh, Et-Te'silul-fikhijju lilu'mlatir-rakmijje - Elbitcoin nemuzedžen, El-Umlatul-iftiradijjetu fil mizan, El-Mu'temer eddevli al-hamis ašere li-kulijjetiš-šeri'ati ved-dirasatil-islamijjeti bidžami'atiš-Šarika, Kitabu vekai'il-mu'temer, 2019.

Hrvatska enciklopedija, mrežno izdanje. Leksikografski zavod Miroslav Krleža, 2021., http://www.enciklopedija.hr/Natuknica.aspx?ID=44191, pristup: 3. 9. 2021.

Ibnu 'Abidin, Reddul-muhtari ala ed-Duril-muhtar, Darul-fikri, Bejrut, 1992. II izdanje.

Ibnu Kudame, El-Mugni, El-Mektebetul-Kahire,1968.

Ibnu Tejmijje Tekijjuddin Ahmed b. Abdulhalim, Medžmu'ul-fetava, Medžmeul-meliki Fehd, Medina, KSA, 1995.

Jasir b. Abdurrahman Alu Abdusselam, El-Umlatul-iftiradijje, https://ia903401.us.archive.org/16/items/fiqh12001/fiqh12023.pdf, pristup: 20. 8. 2021. 
Kemal b. Humam, Fethul-Kadir, Darul-fikr.

Malik b. Enes, El-Mudevvene, Darul-kutubil-ilmijje, 1994.

Muhamed Osman Šubejr, El-Mu'amelatul-malijjetul-mu'asire fil-fikhilislami, Darun-nefais, Amman, VI izdanje, 2007.

Öğr. Üyesi Adnan ALGÜL, Ahmed Sarhil, El-Bitkvin, mahijetuhu - tekjifuhlfikhijju ve hukmut-te'amuli bihi šer'an, Gümüşhane Üniv. İlahiyat Fakültesi Dergisi, 2019., ISSN: 2146-7900, https://dergipark.org.tr/tr/download/article-file/761699, pristup: 13. 9. 2021.

Proglas Islamskog ekonomskog foruma o legalnosti Bitcoina, br. 1/2018, 11. 1. 2018. https://ar.islamway.net/book/29586/بيان-منتدى-الاقتصاد-الا-سلامي-بشا-ن مشروعية-البتكوين , pristup: 26. 8. 2021.

Urošević Uglješa, Elektronsko poslovanje, https://www.ucg.ac.me/skladiste/blog_22181/objava_56875/fajlovi/EP\% 20_\%207.pdf, pristup: 20. 8. 2021.

Usame Es'ad Ebu Husejn, El-Hukmuš-šer'iju lit-te'amuli bil'umlatil-iftiradijje, El-Umlatul-iftiradijjetu fil mizan, El-Mu'temer ed-devli al-hamis ašere likulijjetiš-šeri'ati ved-dirasatil-islamijjeti bidžami'atiš-Šarika, Kitabu vekai'il-mu'temer, 2019.

\section{INTERNET}

Cointelegraf; https://rs.cointelegraph.com/bitcoin-for-beginners/what-iscryptocurrency, pristup: 20. 8. 2021.

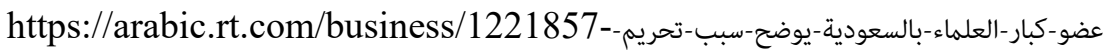

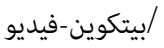

https://capital.com/hr/volatilnost-definicija, pristup: 19. 11. 2021.

https:/hr.encyclopedia-titanica.com/algoritmo, pristup: 19. 11. 2021.

https:/makkahnewspaper.com/article/1111925/أعمال/مجمع-الفقه-الإسلامي-حكم-التعامل/2021

بالعملات-الرقمية-محل-نظر, pristup: 31. 8. 2021.

https://sabq.org/NGZvjV, pristup: 31. 8. 2021.

https://www.moj-bankar.hr/Kazalo/Š/Špekulacija, pristup: 21. 9. 2021.

https://www.youtube.com/watch?v=0bp-SkfovTc, pristup: 31. 8. 2021.

https://www.youtube.com/watch?v=H12kbv6azFs, pristup: 31. 8. 2021. 
https://www.youtube.com/watch?v=KxikLcHuVt0, pristup: 31. 8. 2021.

https:/www.youtube.com/watch?v=L4QVRA9U21w, pristup: 31. 8. 2021.

https://www.youtube.com/watch?v=MRWq-dVmX9Q, pristup: 31. 8. 2021.

https://www.youtube.com/watch?v=QBQMKuJjaUg, pristup: 31. 8. 2021.

https://www.youtube.com/watch?v=rjEJQ0dy89I, pristup: 31. 8. 2021.

Kriptovalute i blockchain - sve što trebate znati, Službene internetske stranice Europske unije, https://ec.europa.eu/croatia/cryptocurrencies_and_blockchain_all_you_ne ed_to_know_hr, pristup: 20. 8. 2021.

Oficijelna stranica Egipatskog vijeća za fetve, https://www.daralifta.org/ar/Viewstatement.aspx?sec=media\&ID=5617, pristup: 26.8 . 2021.

Oficijelna stranica Generalnog vijeća za islamska pitanja Ujedinjenih Arapskih Emirata, fetva br. https://www.awqaf.gov.ae/ar/Pages/FatwaDetail.aspx?did=89043, pristup: 26. 8. 2021.

Palestinsko Vijeće za fetve, fetva br. 1/158, 25.03 .1439 hidž. god., https://staff.ppu.edu/jawad/files/316, pristup: 26. 8. 2021. 
Hakija Kanurić, PhD

University of Bihac

Islamic Pedagogical Faculty

E-mail: bakijak@hotmail.com

\section{CRYPTOCURRENCIES IN THE PRISM OF ISLAMIC LAW}

\section{ABSTRACT}

Throughout a long history of the human community, money has taken various forms, and cryptocurrencies are its latest form. The aim of this paper is to present cryptocurrencies and how they function, what are their advantages and disadvantages and how Islamic law treats them.

To understand the essence of cryptocurrencies, it is necessary to understand several key terms, such as blockechain, private keys, electronic wallets, mining, etc.

One part of Islamic scholars share the view that money is the exclusive name for gold and silver. Coins of any metals different than gold and silver, whose nominal value is higher than the real value, they are not considered as money and treated them as commodities. The other part of the scholars call the money everything that is used as a means of payment in the exchange of goods, whether it is about gold, silver, copper, paper or anything else if it is generally accepted as a means of payment.

Islamic scholars are unanimous in the attitude that minting money, outside of a legitimate mint, is probibited if it represents actual and real harm to the community, and when the damage is possible but not real, regarding the issuance and printing of money by others outside the government, Islamic scholars have two conflicting opinions.

Most modern scholars take a stand that cryptocurrencies, such as Bitcoin, are banned, but a significant proportion of them have remained reticent and a smaller proportion of scholars consider cryptocurrencies as allowed, under certain conditions.

The main arguments of the probibition are the fact that cryptocurrencies are not released or regulated by the state, shrouded in secrecy, they promote illegal activities and the black market, they are unstable and dealing with them looks like hazard and gambling. The permission of cryptocurrencies is based on the universal rule that every thing, basically, is allowed until a valid argument confirms the opposite, and the fact that cryptocurrencies have become valuable property and perform the functions of money.

Key words: cryptocurrencies, Bitcoin, money, electronic money, Islamic law 
الأستاذ المحاضر هاكيا كانوريتش

جامعة بيهاتش

كلية التربية الإسلامية

hakijak@hotmail.com

\section{العملة الافتراضية من منظور الفقه الإسلامي}

\section{الخلاصة}

اتخذت الأموال أشكالاً مختلفة على مدى التاريخ الطويل للمجتمع البشري، والعملة التها

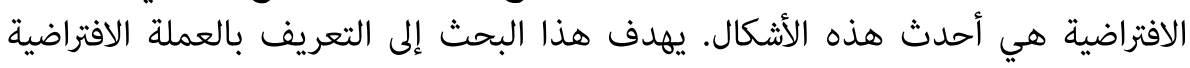

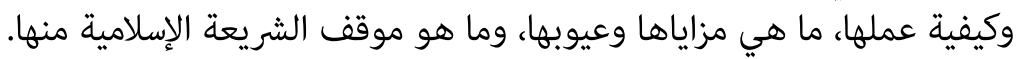
لفهم صلب العملة الافتراضية، من الضروري فهم العديد من المصطلحات الأساسية، مثل:

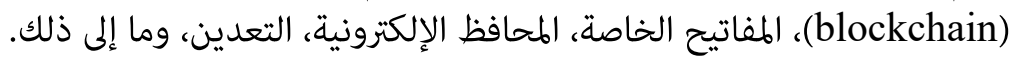

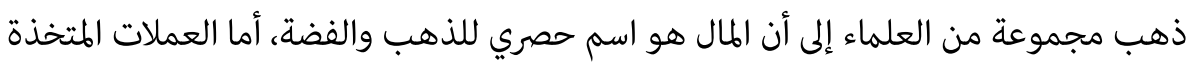

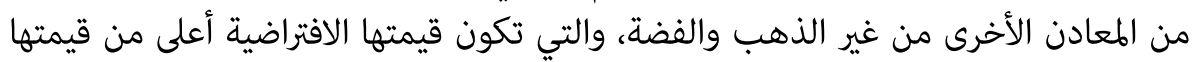

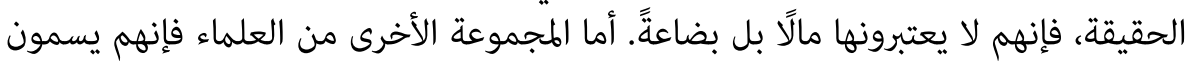

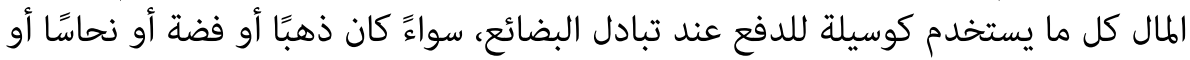

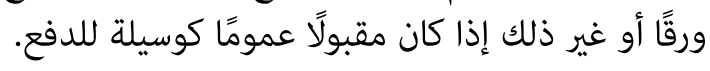

اتفق علماء الإسلام على أن اتخاذ عملة غير العملة النظامية في الدولة غير جائز إذا كان هذا

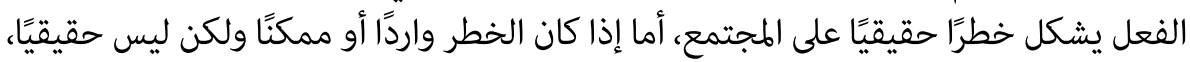

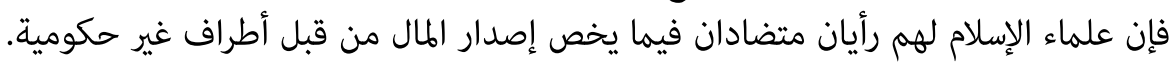
يرى معظم العلماء المعاصرين أن العملات الافتراضية مثل البتكوين (Bitcoin) غير جائزة، بينما ظل عدد إنها كبير منهم متحفظًا بهذا الشأن، ونسبة قليلة منهم اعبرت العملات الافتراضية جائزة وفقًا لشروط معينة.

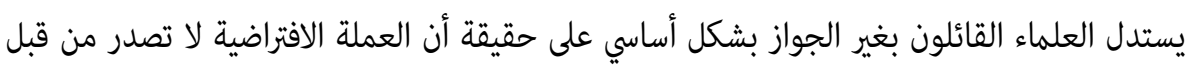

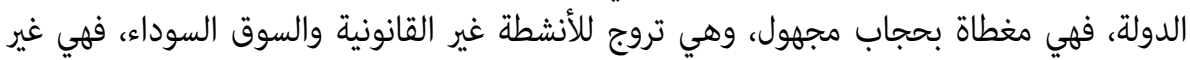

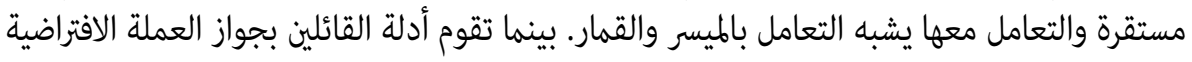

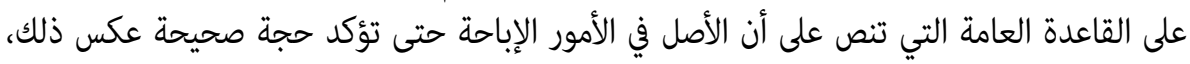

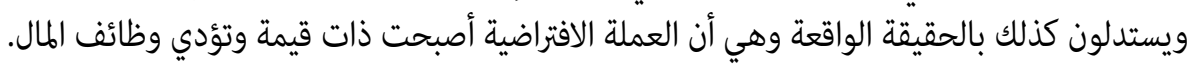
الكلمات المفتاحية: العملة الافتراضية، بتكوين، مال، الأموال الإلكترونية، الفقه الإسلامي. 